\title{
Understanding and Exploiting Post-Translational Modifications for Plant Disease Resistance
}

\author{
Catherine Gough and Ari Sadanandom*
}

Department of Biosciences, Durham University, Stockton Road, Durham DH1 3LE, UK; catherine.gough@durham.ac.uk

* Correspondence: ari.sadanandom@durham.ac.uk; Tel.: +44-1913341263

check for updates

Citation: Gough, C.; Sadanandom, A Understanding and Exploiting Post-Translational Modifications for Plant Disease Resistance. Biomolecules 2021, 11, 1122. https://doi.org/ 10.3390/biom 11081122

Academic Editors: Giovanna Serino and Daisuke Todaka

Received: 6 July 2021

Accepted: 26 July 2021

Published: 30 July 2021

Publisher's Note: MDPI stays neutral with regard to jurisdictional claims in published maps and institutional affiliations.

Copyright: (c) 2021 by the authors. Licensee MDPI, Basel, Switzerland. This article is an open access article distributed under the terms and conditions of the Creative Commons Attribution (CC BY) license (https:// creativecommons.org/licenses/by/ $4.0 /)$.

\begin{abstract}
Plants are constantly threatened by pathogens, so have evolved complex defence signalling networks to overcome pathogen attacks. Post-translational modifications (PTMs) are fundamental to plant immunity, allowing rapid and dynamic responses at the appropriate time. PTM regulation is essential; pathogen effectors often disrupt PTMs in an attempt to evade immune responses. Here, we cover the mechanisms of disease resistance to pathogens, and how growth is balanced with defence, with a focus on the essential roles of PTMs. Alteration of defence-related PTMs has the potential to fine-tune molecular interactions to produce disease-resistant crops, without trade-offs in growth and fitness.
\end{abstract}

Keywords: post-translational modifications; plant immunity; phosphorylation; ubiquitination; SUMOylation; defence

\section{Introduction}

Plant growth and survival are constantly threatened by biotic stress, including plant pathogens consisting of viruses, bacteria, fungi, and chromista. In the context of agriculture, crop yield losses due to pathogens are estimated to be around $20 \%$ worldwide in staple crops [1]. The spread of pests and diseases into new environments is increasing: more extreme weather events associated with climate change create favourable environments for food- and water-borne pathogens [2,3].

The significant estimates of crop losses from pathogens highlight the need to develop crops with disease-resistance traits against current and emerging pathogens. Crop protection methods have low effectiveness against pathogens, which includes fungicides and insecticides which control insect viral transmissions; moreover, resistance against these chemicals is increasing [4,5]. Resistance refers to the inability of a pathogen to complete its life cycle on that plant species [6]; targeting host resistance for improvement is the most economical and effective method for controlling the reduction in crop losses to disease [7-9].

Developing novel solutions to this increasing problem requires a deeper understanding of plant defence mechanisms. Beyond gene expression and transcriptomics, proteomics is particularly useful as it can directly measure relative protein abundance, as well as detecting post-translational modifications (PTMs) [10]. PTMs can activate, deactivate, or change protein function to induce or attenuate specific plant responses. Analysis at the protein level can reveal pathogen host targets, protein turnover, and protein-protein interactions in defence signalling for the purpose of modifying and boosting immunity in crops [11]. This review outlines the functions of PTMs in immunity and the potential to manipulate PTMs to enhance disease resistance.

\section{The Framework of Plant Defence}

Due to their sessile nature, plants rely heavily on chemical defences against biotic and abiotic stresses [11]. Plants are constantly challenged by biotic stresses: pathogen infection 
harms plant growth, reproduction, and survival. Plants have defence systems to overcome or reduce pathogen attacks, which include physical barriers to prevent pathogen entry and an innate immune system to respond to pathogen attacks [12].

The inducible plant innate immune system is made up of PAMP-triggered immunity (PTI) and effector-triggered immunity (ETI) which significantly overlap (Figure 1) [13-16]. Arabidopsis (Arabidopsis thaliana) is used as the predominant model system to study the molecular events of the defence signalling pathway, but the overall system is conserved in monocots and dicots [17]. Conserved molecular structures from microbes known as pathogen-associated molecular patterns (PAMPs) are recognised by cell-surface pattern recognition receptors (PRRs), triggering downstream immune responses $[13,18,19]$. Welldefined PAMP-PRR interactions are bacterial flagellin peptide flg22 and its cognate receptor FLAGELLING-SENSING 2 (FLS2) [20,21], bacterial elongation factor thermal unstable (EF$\mathrm{Tu}$ ) and its receptor EF-Tu receptor (EFR) [22,23], and fungal cell wall polysaccharide chitin and its receptor CHITIN ELICITOR RECEPTOR KINASE 1 (CERK1) [24,25]. These PRRs are receptor-like kinases which initiate a phosphorylation cascade to activate defence-related enzymes or genes [26] (Figure 1).

Several effectors are secreted by the pathogen to disrupt cellular function throughout infection. Unlike PAMPs, effectors are diverse and include proteins, sRNAs, chemicals, toxins, and hormones which increase pathogen infection by benefiting the pathogen or suppressing host defence. Intracellular receptors called nucleotide-binding domain, leucinerich repeat-containing proteins (NLRs, also known as NB-LRRs) detect specific effectors delivered into the plant cell to trigger effector-triggered immunity (ETI). NLRs can themselves detect effectors or function as helpers to trigger signal transduction [27]. Detection by NLRs is either directly (receptor-ligand model) or, in most cases, indirectly through the 'guard' or 'decoy' mechanisms [28,29]. The two major groups of NLRs are Toll-interleukin-1 receptor-like nucleotide-binding site leucine-rich repeat (TNL) and coiled-coil (CC)-NBSLRR (CNL) [27,30]. Furthermore, resistance to powdery mildew 8 (RPW8)-NBS-LRRs (RNLs) function as helper NLRs [31,32]. Proteins downstream of NLR activation include NON-RACE-SPECIFIC DISEASE RESISTANCE 1 (NDR1) and ENHANCED DISEASE SUSCEPTIBILITY 1 (EDS1) [33] (Figure 1). These pathways lead to outcomes including accumulation of salicylic acid and defence gene activation [34,35].

Molecular and physiological changes induced downstream of PRRs and NLRs include mitogen-activated protein kinase (MAPK) activation, production of reactive oxygen species (ROS), stomata closure, defence gene expression, hypersensitive response (HR) and cell death, callose deposition and lignification, reduction of photosynthesis, increased respiration and expression of PATHOGENESIS-RELATED (PR) proteins, and production of antimicrobial compounds [10,11,36-38]. Pathogen perception triggers changes in hormone levels including salicylic acid (SA) which mediates defences against biotrophs and hemi-biotrophs and jasmonic acid (JA)/ethylene which mediates defences against necrotrophs [39].

The understanding of the plant defence response in the model organism Arabidopsis or in crops is not complete. Many studies have relied on genomic or transcriptomics; however, transcriptional changes do not reflect the complete cellular regulatory processes, since posttranscriptional processes that alter the amount of active protein, synthesis, degradation, processing, and modification of proteins are not taken into account. Thus, complementary approaches such as proteome-based expression profiling are needed to obtain a full picture of the regulatory elements in plant-pathogen interactions [40]. At almost every stage of defence, PTMs are important, allowing fast activation and signalling; PTMs act as molecular switches to alter protein functions rapidly [41,42]. This review considers PTMs in crop improvement, among other approaches. PTMs modification may offer a more nuanced approach and provoke less of a yield penalty than gene knockouts or gene introduction. 


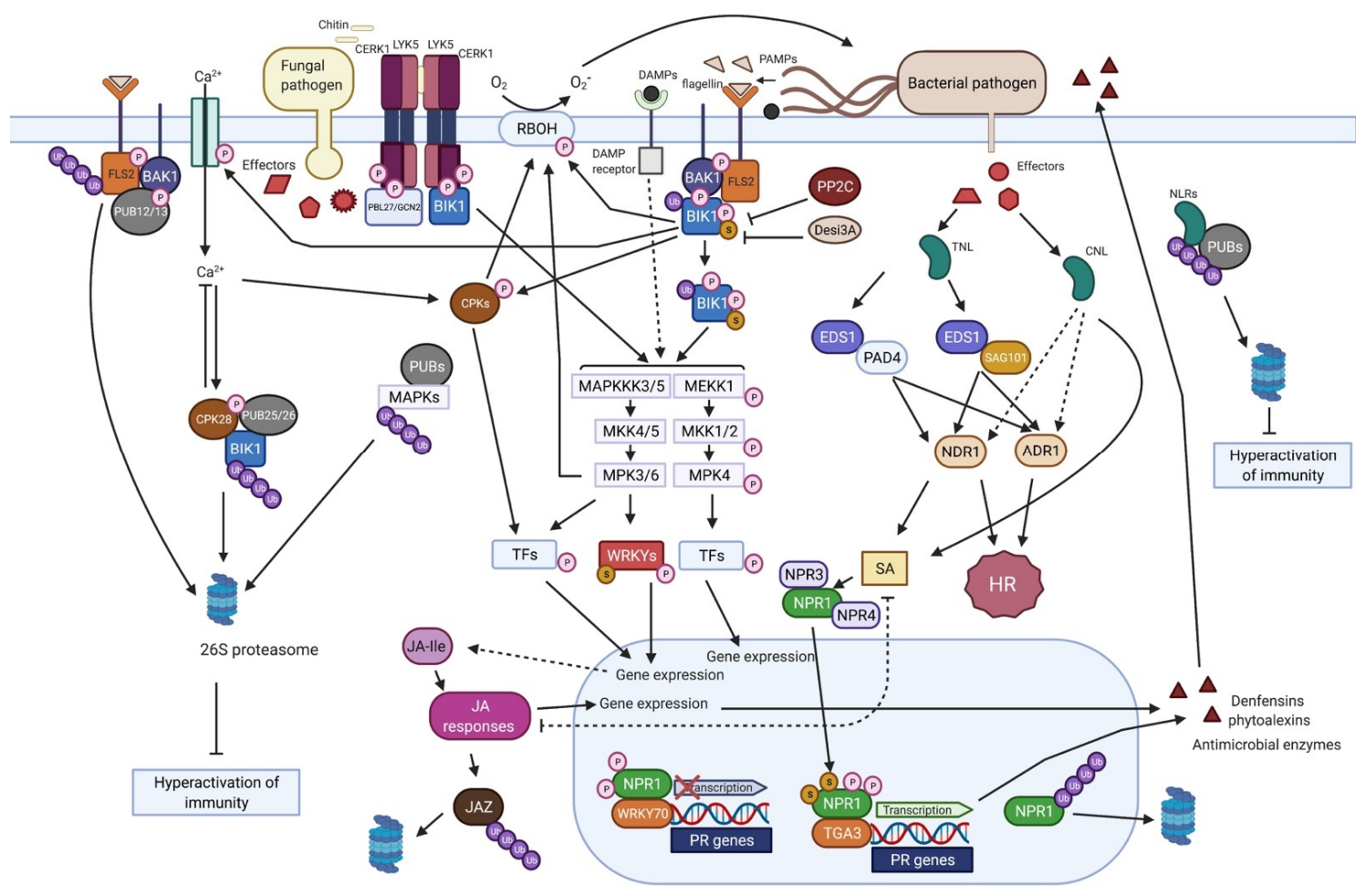

Figure 1. The framework of plant immunity. Briefly, microbe-derived pathogen-associated molecular patterns (PAMPs) and host damaged-associated molecular patterns (DAMPs) are perceived by cell-surface pattern recognition receptors (PRRs), which along with coreceptors activate downstream phosphorylation cascades and induce increased $\left[\mathrm{Ca}^{2+}\right]$ and reactive oxygen species (ROS) accumulation. ROS can act as second messengers to cause stomatal closure and directly have antimicrobial effects. Pathogen effectors are perceived by intracellular receptors, NUCLEOTIDE BINDING SITELEUCINE-RICH-REPEAT (NLRs also known as NB-LRRs), which activate downstream responses including Salicylic acid (SA)accumulation. SA and Jasmonic Acid (JA) accumulate in response to pathogens and largely work antagonistically to biotrophic and necrotrophic pathogens, respectively. Outcomes of defence signalling include changes to gene expression, production of (PR) proteins, and biosynthesis of antimicrobial metabolites. Post-translational modifications (PTMs) are involved in all aspects of plant immunity controlling activation, protein interactions, subcellular localisation, and protein turnover. Further details in the main text. P, phosphate group. S, SUMO. Ub, Ubiquitin. Solid lines indicate direct interactions, dashed lines indicate indirection interactions. FLS2, FLAGELLIN-SENSING 2; BAK1, BRI1-ASSOCIATED RECEPTOR KINASE; BIK1, BOTRYTIS-INDUCED KINASE 1; EDS1, ENHANCED DISEASE SUSCEPTIBILITY 1; CERK1, CHITIN ELICITOR RECEPTOR KINASE 1; LYK5, LYSM-CONTAINING RECEPTOR-LIKE KINASE 5; NPR, NONEXPRESSOR OF PATHOGENESIS-RELATED GENES; TGA3, TGA 1a-related gene; CPK, CALCIUM-DEPENDENT PROTEIN KINASES; NDR1, NON-RACE-SPECIFIC DISEASE RESISTANCE 1; ADR1, ACTIVATED DISEASE RESISTANCE 1; PAD4, PHYTOALEXIN DEFICIENT 4; SAG101, SENESCENCE-ASSOCIATED GENE 101; PUB, PLANT U-BOX; HR, hypersensitive response; JAZ, JASMONATE-ZIM-DOMAIN PROTEIN 1; Desi3A, DeSUMOylating isopeptidase 3A, PPCA, PROTEIN PHOSPHATASE TYPE 2C. PBL27/GCN2, GENERAL CONTROL NONREPRESSED 2, RBOH, respiratory burst oxidase homolog; TFs, transcription factors; JA-Ile, jasmonoyl-isoleucine; TNL, Toll-interleukin-1 receptor-like nucleotide-binding site leucine-rich repeat; CNL, coiled-coil (CC)-NBS-LRR. Figure created with Biorender.com.

\section{Post-Translational Modifications Have a Critical Role in Defence}

Post-translational modifications are critical for plant defence responses and are involved in almost every aspect of plant growth and development. PTMs allow protein function to be extended above that of its structure determined by the primary amino acid sequence to control almost all characteristics of protein function. PTM systems are targeted by numerous pathogen effectors; thus, PTMs are worthwhile to investigate in terms of modification and exploitation in crops. This work will focus on phosphorylation, ubiquitination, and SUMOylation, the most well-studied PTMs, which are reversible (Figure 2). Others to briefly mention are N-myristoylation, S-acylation, S-nitrosylation, 
acetylation, glycosylation, sulphenylation, and redox modification, which also have roles in immunity [42,43] but are not covered in this review. Reversibility is crucial to regulate the intensity and duration of protein activity and defence response [44].

\section{Phosphorylation}

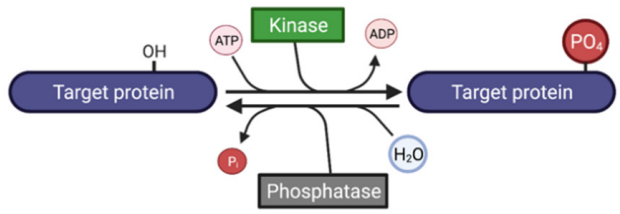

\section{Ubiquintination}
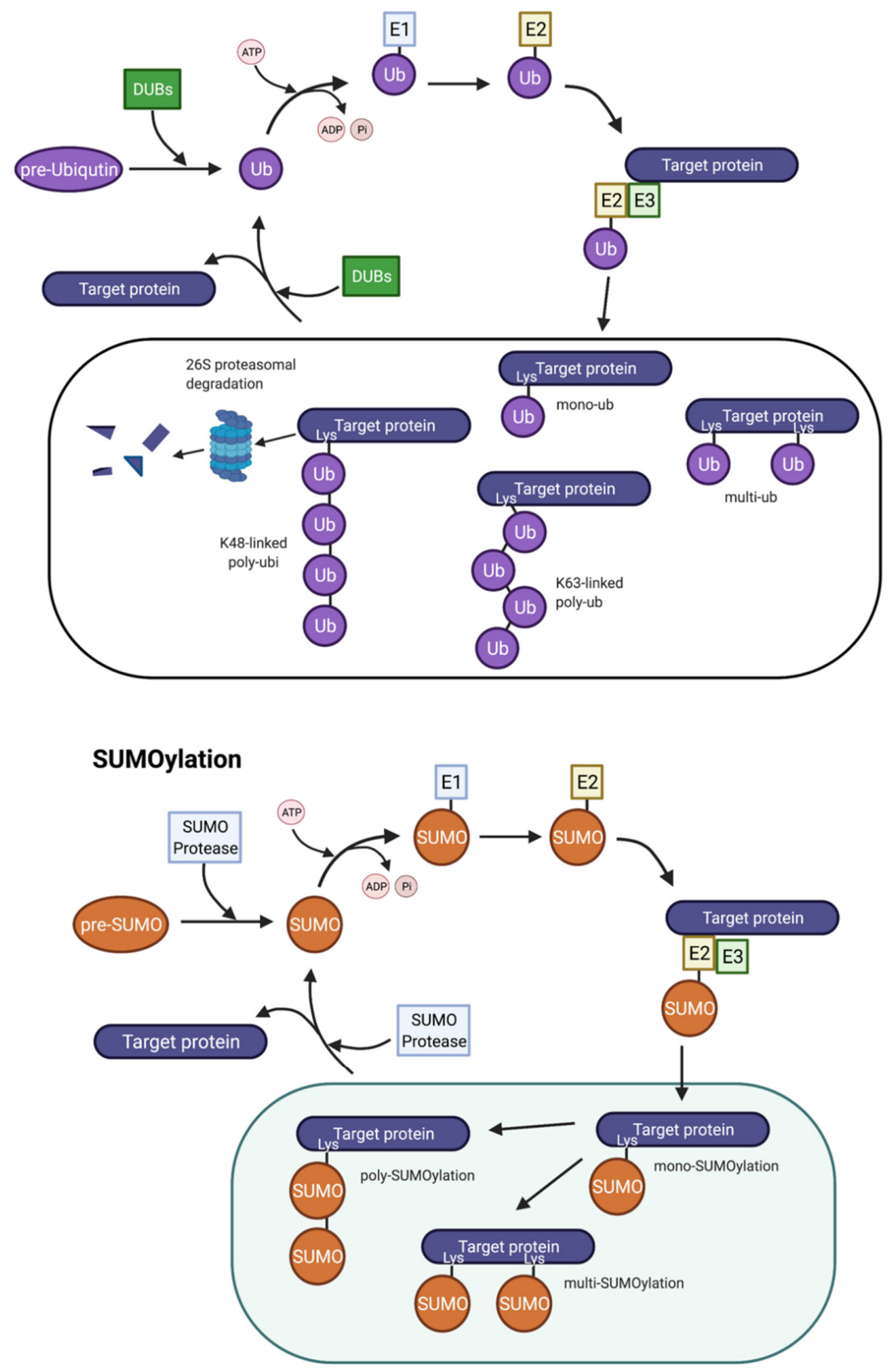

Figure 2. Post-translational modification pathways. Phosphorylation is the process catalysed by protein kinases in which a phosphate group $\left(\mathrm{PO}_{4}\right)$ is transferred from ATP onto the side-chain hydroxyl groups on serine, threonine, or tyrosine residues on a target protein. Phosphatases hydrolyse 
the phosphoester bond to remove the phosphate group. Ubiquitination involved the sequential action of the ubiquitin-activating enzymes (E1), ubiquitin-conjugating enzymes (E2), and ubiquitin-protein ligases (E3) to covalently attach ubiquitin onto the target lysine. Different ubiquitin attachment linkages and chain lengths have different functions; for example, K48-linked tetraubiquitin targets the protein for 26S proteasomal degradation. Deubiquitinating enzymes (DUBs) catalyse deubiquitination. SUMOylation is analogous to ubiquitination and involves the sequential action of SUMO E1, E2, E3 enzymes to covalently attach SUMO onto the target lysine. SUMO is synthesised as an inactive precursor which has its C-terminal peptide cleaved by a SUMO protease exposing the di-glycine motif. SUMO proteases also catalyse the removal of SUMO.

\subsection{Phosphorylation}

Phosphorylation is paramount in several aspects of immunity to control enzyme activity and in signalling. Phosphorylation is crucial in PRR downstream responses through phosphorylation cascades; phosphorylation is a rapid and transient switch (Figure 2) and is essential in immune signal transduction [42]. Ligand perception in several PRRs stimulates the recruitment of coreceptor BRI1-ASSOCIATED RECEPTOR KINASE (BAK1) (also known as SOMATIC EMBRYOGENESIS RECEPTOR KINASE 3 (SERK3)), which heterodimerises with several receptor-like-kinases (RLKs) including FLS2, BRASSINOSTEROID INSENSITIVE-1 (BRI1), and EFR [45]. BAK1 is differentially phosphorylated when in complex with different PRR complexes [46]. BOTRYTIS-INDUCED KINASE 1 (BIK1) is a substrate of BAK1 and the pair feature in many defence signalling pathways. Autophosphorylation and transphosphorylation are essential by both BIK1 and BAK1 in their interaction and interaction with other downstream components in signal transmission [45]. BIK1 dissociation activates downstream signalling, such as activation of MAPK cascades, transcriptional reprogramming, and ROS production [47,48]. BIK1 directly phosphorylates respiratory burst oxidase homologue protein $\mathrm{D}(\mathrm{RbohD})$, an NADPH oxidase which produces ROS burst to induce stomatal closure and act as antimicrobial molecules $[49,50]$.

BAK1 is a key kinase in plant immunity which possesses numerous phosphorylation sites itself to regulate specific outputs, as shown by mutagenesis studies. Some phosphorylation sites have positive effects, and some have negative effects on BAK1 function [51,52]. The T455A (threonine-to-alanine) mutation abolishes BAK1 kinase activity, and the conserved BAK1 residue Y403 is important for ligand-induced activation of the immune receptor complex [53]. Phosphorylation patterns are specific to mediate the response allowing BAK1 to regulate defence and brassinosteroid signalling. For example, it was suggested that specific BAK1 mutant variants $\mathrm{BAK} 1^{\mathrm{C} 408 \mathrm{Y}}$ and $\mathrm{BAK} 1^{\mathrm{T} 450 \mathrm{~A}}$ provoke differential phosphorylation patterns on specific receptors. This conclusion was drawn as the mutant phenotypes BAK $1^{\mathrm{C} 408 \mathrm{Y}}$ and $\mathrm{BAK} 1^{\mathrm{T} 450 \mathrm{~A}}$ show impaired defence signalling but with wildtype (WT)-like BAK1-mediated brassinosteroid (BR) signalling $[53,54]$. These phenotypes are different from the BAK1 null allele; thus, clear mutations in specific residues can alter phenotype [46,55]. Interestingly, the mutation in C408 reduced phosphorylation of Y403, shown using a specific pY403 antibody, which highlights that residues surrounding the PTM attachment site can influence PTM status [56]. This mutagenesis approach to potentially mutate residues surrounding the PTM could be advantageous to stabilise/destabilise PTMs without blocking the PTM formation, to make interactions reduced or enhanced in some circumstances.

It is clear that phosphorylation is central to defence in signal transduction [57]; the activation of the MAPKs MPK3, MPK4, and MPK6 (MPK3/4/6) is a hallmark of immune system activation and is crucial for establishing disease resistance [58]. All known PRRs activate two MAPK cascades (Figure 1) consisting of MAPK kinase kinase (MKKK), MAPK kinase (MKK), and MAPKs: MAPKKK3/MAPKKK5-MKK4/MKK5-MPK3/MPK6 which positively regulates defence, and MEKK1 - MKK1/MKK2-MPK4 which negatively regulates immune responses [58-62]. Phosphorylation of downstream substrates such as WRKY transcription factors causes transcriptional changes [63]. For instance, WRKY33 is a substrate of MPK3/6 which activates transcription of PHYTOALEXIN DEFICIENT 
3 (PAD3) encoding a cytochrome P450 enzyme (CYP71B15) which carries out the last step of camalexin biosynthesis, causing induction of camalexin, which has antimicrobial effects $[63,64]$. Additionally, MPK3/6 activation is critical to including inhibition of photosynthesis to promote ROS accumulation in chloroplasts and HR cell death [65]. Moreover, MPK4 is targeted by Pseudomonas syringae bacterial type III effector HopAI1 and acts as the guardee of NLR SUPPRESSOR OF MKK1 MKK2 2 (SUMM2) [66]. Disruption of the MEKK1-MKK1/2-MPK4 kinase cascade results in constitutive immune responses mediated by the NLR protein SUMM2 [67].

Reversibility is paramount to control phosphorylation states to regulate signal transduction, constitutive activation of defence leads to growth defects [68]. Phosphorylation of PRR complexes including FLS2-BAK1-BIK1 is negatively regulated by PROTEIN PHOSPHATASE TYPE 2A (PP2A) and PROTEIN PHOSPHATASE TYPE 2C (PP2C) [42,69,70]. Similarly, CERK1-INTERACTING PROTEIN PHOSPHATASE 1 (CIPP1) dephosphorylates CERK1, in the absence of chitin, to negatively regulate CERK1 signalling [71]. Phosphatases ARABIDOPSIS PHOSPHATASE 2Cs (AP2Cs) interact with MPK3, 4, and 6 to negatively regulate innate immunity against necrotrophic fungal pathogen Botrytis cinerea [72,73]. MAP KINASE PHOSPHATASE1 (MKP1) and PROTEIN TYROSINE PHOSPHATASE1 (PTP1) act as repressors of inappropriate MPK3/MPK6-dependent stress signalling [74,75]. Additionally, phosphorylation can lead to feedback dephosphorylation; for example, MKP1 is phosphorylated by MPK6, one of MKP1's substrates [76].

\subsection{Ubiquitination}

Ubiquitin $(\mathrm{Ub})$ is covalently attached to specific lysine residues of target proteins through an enzymatic cascade, which is reversible (Figure 2) [77]. Most ubiquitylated proteins, especially those modified with lysine48(K48)-linked polyubiquitin chains, are targeted for degradation by the $26 \mathrm{~S}$ proteasome $[78,79]$. Nevertheless, ubiquitination has several functions including signalling, endocytic trafficking, etc., dependent on the specific attachment linkage $[80,81]$. The ubiquitin system is required for innate immunity and its regulation [82,83]. For example, expression of a ubiquitin variant with a K48R (lysine-toarginine) change prevents K48 attachments (Figure 2) and alters the responses to viruses in tobacco [82]. K48 is one of the most abundant ubiquitin attachments that cause ubiquitinmediated proteasomal degradation, although other linkages may be involved [77,84]. Different enzymes of ubiquitin machinery impact immunity. Arabidopsis has two Ub E1s, UBIQUITIN ACTIVATING ENZYME 1 (UBA1) and UBA2, which are partially redundant. The null mutant of UBA1, mos1, is defective in innate immunity, whereas the $u b a 2$ null mutant plants do not have defects in immunity. It was shown that the activation and downstream signalling of several resistance $(R)$ proteins requires Ub E1 UBA1 [83].

Many E3 ubiquitin ligases are involved in plant immunity by carrying out ubiquitination to target substrates [85]. Ubiquitination is essential to regulate levels of plant immune system components through protein turnover to avoid excessive or inappropriate responses. This is illustrated by the plant $u$-box 13 (pub13) mutant which has enhanced immune responses on pathogen attack or flg22 perception. However, the pub13 mutant demonstrates autoimmune responses, namely, causing spontaneous cell death and accumulation of ROS in the absence of stress, which shows the importance of PTM regulation [86]. It was further shown that FLS2 is specifically polyubiquitinated by ubiquitin E3 ligases PUB12/13 which target FLS2 for degradation. Interestingly, phosphorylation by BAK1 activates PUB12/13 after FLS2 binds flagellin, demonstrating the feedback attenuation of FLS2 responses and the reliance on multiple PTMs in defence regulation [86]. BAK1 kinase activity is essential in mediating its interaction with PUB13 since the BAK1 kinase-inactive mutant which has the K317M substitution could no longer interact with PUB13 [87]. PUB13 also ubiquitinates LYSM-CONTAINING RECEPTOR-LIKE KINASE 5 (LYK5), targeting it for degradation to regulate chitin-triggered defences (Figure 1) [88]. Ub E3 ligase PUB25/26 targets nonactivated immune kinase BIK1 for degradation to modulate BIK1 levels (Figure 1) [89]. PUB4 interacts with CERK1 and is a positive regulator of chitin-induced immune responses [90]. 
Overaccumulation of NLRs often leads to autoimmune responses. In order to prevent this, NLR proteins SUPPRESSOR OF NPR1-1, CONSTITUTIVE 1 (SNC1), and RESISTANT TO P. SYRINGAE 2 (RPS2) are targeted for ubiquitination and degradation by the SKP1CULLIN1-F-box (SCF) complex (Cheng et al., 2011). In contrast, Arabidopsis Ub E3 ligases RPM1 INTERACTING PROTEIN 2 and 3 (RIN2 and RIN3) contribute positively to NLRs RESISTANCE TO P. SYRINGAE PV. MACULICOLA 1 (RPM1)- and RPS2-dependent HR (Kawasaki et al., 2005).

Ubiquitination is essential to allow activation of JA responses against necrotrophs. JASMONATE-ZIM-DOMAIN PROTEIN 1 (JAZ) proteins function as transcriptional repressors of JA-responsive genes [91]. Bioactive JA (jasmonoyl-isoleucine (JA-Ile) conjugate) promotes the physical interaction between the ubiquitin ligase complex SCFCOI1 and JAZ proteins to cause ubiquitin-mediated proteasomal degradation of JAZ, to allow expression of JA-dependent genes [91-93].

Although Ub E3s largely determine the substrate specificity [94-97], deubiquitinating enzymes (DUBs) also have substrate specificity [80,98]. This is important in immunity; for example, deubiquitinating enzymes Arabidopsis UBIQUITIN-SPECIFIC PROTEASE 12 and 13 (AtUBP12 and AtUBP13) were found to negatively regulate plant immunity [99]. However, UBP12 and UBP13 are positive regulators of JA responses and may act by stabilising MYC, resulting in the JA pathway suppressing SA-mediated immunity [100].

\subsection{SUMOylation}

Besides ubiquitin, ubiquitin-like polypeptides are covalently conjugated to substrates in eukaryotes via the substrate lysine (Figure 2). Small ubiquitin-like modifier (SUMO) is another important PTM involved in plant biotic stress responses. Global SUMOylome changes occur on pathogen attacks [101-104]. For example, the auto-immune suppressor of rps4-rld1-4 (srfr1-4) mutants showed large increases in basal SUMO1/2-conjugates, as did wild-type plants challenged with Pseudomonas Syringae pv. tomato (Pst)DC3000, compared to the WT untreated plants. Overall, the srfr1-4 mutant and PstDC3000 infected WT plants were found to share $57.9 \%$ of their common SUMO substrates which consist of wideranging targets. The autoimmune srfr1-4 plants have increased SA levels and constitutive upregulation of PR1/PR2 genes; stunted growth is also observed [105]. Significantly, loss of EDS1 restores the SUMOylome in srfr1-4 to wild-type (Col-0) levels and abolishes growth retardation and autoimmunity [106]. Therefore, SUMOylation and deSUMOylation are crucial for defence regulation.

Different SUMO paralogues have different functions, and different paralogs exist in different species [107]. In Arabidopsis, SUMO1/2 inhibits SA-mediated defence responses in the absence of pathogen [108]. In contrast, SUMO3 promotes plant defence responses downstream of SA [109]. SUMO also forms noncovalent interactions with proteins via SUMO interacting motifs (SIMs) which facilitate interactions between SUMO-conjugated proteins and protein partners featuring SIM site(s) for protein complex formation [107,110].

Altering the specific pattern of PTMs changes the plant's defence responses and ability to resist disease. For instance, the OVERLY TOLERANT TO SALT1 and -2 (OTS1/2) SUMO protease double mutant ots1ots2 accumulates increased levels of SUMO conjugates, higher levels of SA, and enhanced resistance to PstDC3000, compared to WT plants. It was found that SUMO proteases OTS1 and OTS2 limit SA biosynthesis by suppressing ISOCHORISMATE SYNTHASE1 (ICS1) expression, and as a feedback mechanism, SA promotes the degradation of OTS1 and OTS2 in order to modulate SA signalling [101]. Similarly, SUMO protease mutants early in short days 4 (esd4) have high SA accumulation [111]. These show that the SUMO enzymatic machinery regulates SA-mediated defence to adjust the response appropriately [101,109].

Another aspect of SUMO machinery to affect defence is portrayed by the sap and miz 1 (siz1) SUMO E3 ligase Arabidopsis loss-of-function mutant. siz1 plants have decreased SUMO conjugates, dwarfism, an autoimmune phenotype, characterised by increased accumulation of SA, increased expression of EDS1, PAD4, and PATHOGENESIS-RELATED 
$(P R)$ genes, and greater resistance to the bacteria PstDC3000, compared to WT plants [112]. The siz1 autoimmune phenotype is dependent on the TNL immune receptor SNC1 [113,114]. TOPLESS-RELATED 1 (TPR1), an SNC1-interacting protein, physically interacts with and is SUMOylated by SIZ1 [115]. Mutation of K282 and K721, the critical SUMOylation attachment sites of TOPLESS-RELATED 1 (TPR1) suggested that TPR1 SUMOylation represses immunity through repression of its own transcriptional co-repressor activity. This leads to the expression of negative regulators of immunity DEFENSE NO DEATH 1 (DND1) and DND2. In addition, SNC1 is SUMOylated, which perhaps further acts to repress immunity in the absence of pathogens $[113,115]$. SNC1 transcription is controlled by SUMOylation, as well as SNC1 being SUMOylated at the protein level [113], and SNC1 protein level is controlled by ubiquitin-mediated degradation, as mentioned in the previous section [116]. It is important to control SNC1 activity to avoid excessive immune responses, which would be detrimental to plant growth and cause damage [117].

Disruption of the PTM enzymatic machinery underlines the fact that changes in PTM attachment/removal have profound effects on plant physiology, including regulation of defence.

Interestingly, increased SUMOylation in ots1ots2 mutants or reduced SUMOylation siz1 mutants have increased SA levels indicating the complexity in PTM regulation, and that SUMOylation regulation is key to modulate the correct level of immunity. This tight control of SUMO is further highlighted as overexpression of the three Arabidopsis SUMO (SUM) genes resulted in activation of SA-dependent defence responses, as did the sum1sum2 knockdown mutant [109].

In addition to SA signalling, SUMO has a role in modulating JA signalling. SUMOconjugated to JAZ inhibits the JA Receptor CORONATINE INSENSITIVE1 (COI1) through the COI1 SIM site [118]. SUMO protease OTS1/2 action or degradation determines if the JA response is activated or inhibited, dependent on the type of pathogen [118]. Significantly, SUMOylation interacts with other PTMs including phosphorylation and ubiquitination which will be outlined in the subsequent section.

\subsection{Interaction between PTMs}

Most aspects of immunity are regulated by multiple PTMs, which often interact. PTMs undergo crosstalk and have a mutual dependence. One prominent example is FLS2 signalling whose regulation requires phosphorylation, SUMOylation, and ubiquitination $[48,86,119]$. In uninfected conditions, FLS2 associates with BIK1 [21,120]. When flg22 is detected, FLS2 recruits coreceptor protein kinase BAK1 which allows BIK1 and BAK1 to undergo reciprocal phosphorylation [55,121,122]. Additionally, on flagellin perception, FLS2 is SUMOylated on lysine1120, triggering the release of BIK1, which is essential for the FLS2-mediated defence response. DeSUMOylating isopeptidase 3A (Desi3A) deSUMOylates FLS2 to negatively regulate immune signalling in the absence of flagellin. Yet, when flagellin is detected, Desi3A is degraded to enhance levels of SUMOylated FLS2 and increase immune signalling (Figure 1) [48]. In addition, it was found that monoubiquitination of BIK1 contributes to ligand-induced BIK1 dissociation from receptor FLS2 [123]. As mentioned previously, PUB12/13 triggers the degradation of FLS2 via the ubiquitin-proteasome system.

Post-translational modification on PTM machinery enzymes also occurs in defence; for example, CALCIUM-DEPENDENT PROTEIN KINASE 28 (CPK28) phosphorylases and activates $\mathrm{Ub}$ E3 ligases PUB25 and 26 to enhance ubiquitination and proteasomal degradation of nonactivated BIK1 (Figure 1) [89,124]. Interactions between Ub E3 ligases and the kinase domains appear to be common in the regulation of RLKs [125].

NONEXPRESSOR OF PATHOGENESIS-RELATED GENES (NPR1) is a key transcription factor in defence as it regulates the expression of $P R$ genes contributing to the establishment of systemic acquired resistance (SAR) [126]. Again, phosphorylation, SUMOylation, and ubiquitination are essential for its function for appropriate defence responses (Figure 1). SUMOylation interacts with phosphorylation to control NPR1 functions: phosphoryla- 
tion of Ser55 and Ser59 prevents NPR1 SUMO attachment. SUMOylation status of NPR1 alters its interaction with partners. Non-SUMOylated NPR1 interacts with WRKY70 to repress the expression of the PR1. On pathogen challenge, SA accumulation promotes dephosphorylation of Ser55/Ser59, allowing NPR1 to become SUMOylated, provoking NPR1 to interact with TGA3 to promote PR1 gene expression $[127,128]$. Furthermore, NPR1 interaction with SUMO3 is required for Ser11/Ser15 phosphorylation, which causes ubiquitination and degradation by the NPR3-CULLIN3 E3 complex for specific and transient immune induction [129]. NPR1 degradation is important for the full range of defence gene activation and for activation of ETI and programmed cell death at the infection site, where SA levels are high [126], whereas in neighbouring cells SA levels are intermediate to allow NPR1 function [130]. SA-induced PR genes encode several antimicrobial metabolites including endoglucanases, chitinases, defensins, etc. [131]. This cited example displays that phosphorylation sites have opposing functions and that specific PTM patterns give outcomes in terms of defence response. The multiple-PTM sequential process provides more precise control to allow ubiquitin-mediated degradation at the right time when pathogens are not detected [132]. NPR1 has a functionally conserved role in crops; thus, potentially SUMO is involved in the regulation of orthologues similar to Arabidopsis, but this needs investigation $[126,133]$.

Significant crosstalk exists between SUMOylation and ubiquitination, particularly as part of negative feedback to induce protein's own degradation; for example, SIZ1 can SUMOylate CONSTITUTIVE PHOTOMORPHOGENIC 1 (COP1), which enhances the trans-ubiquitination activity of COP1, a multi-subunit E3 ligase which positively regulates disease resistance against viruses [134,135]. Following SUMOylation, COP1 ubiquitinates SIZ1 causes its degradation; therefore, ubiquitination regulates cellular SUMOylation by regulating SIZ1, as well as SIZ1 promoting COP1 ubiquitination activity [136].

Several SUMO targets overlap with MAPK phosphorylation targets in immunity regulation [137]. Several WRKYs were identified as targets of SUMO1 by proteomics, as well as MAPK phosphorylation [104]. To support this, it was exhibited that in response to Botrytis cinerea infection and flg22 elicitor treatment, WRKY33 is SUMOylated, which allows WRKY33 phosphorylation by MPK3/ 6 for activation of transcription factor activity leading to increased camalexin biosynthesis (Figure 1) [138].

It is clear that PTMs are vital for plant defence responses and disease resistance in Arabidopsis, and following this finding, PTMs are illustrated as similarly important in crop species and represent an excellent resource to be exploited in crop improvement. General mechanisms of immunity are similar in Arabidopsis and crop species along with classes of proteins; however, precise mechanisms, interactions, protein complexes, and PTMs are specific to the species and variety [17]. One study found that 1619 phosphosites in Arabidopsis aligned exactly to phosphosites of any other plant species, indicating some similarities in protein phosphorylation in Arabidopsis and crops [139]. In several cases, defence protein orthologues show a conserved role among different plant species; for example, PRRs, MAPK cascades, WRKY TFs, NPR1, ubiquitin ligases, and ubiquitination-mediated proteasomal degradation modulate defence protein accumulation $[80,81,126,133,140-144]$.

In rice, differences in disease resistance may depend on the PTM pattern, as was suggested by the finding that the number and distribution of phosphorylation motifs differ between resistant and susceptible alleles of Pi54 [145,146]. Findings of PTM crosstalk in crops prove that PRR-mediated signalling in rice depends on specific phosphorylation patterns and ubiquitin-mediated control. The XA21 Thr705 residue is essential for rice PRR XA21 autophosphorylation. Thr705 is also essential for the interaction between XA21 and rice XA21 binding protein 3 (XB3) a ubiquitin ligase which is required for full XA21-mediated resistance $[147,148]$. This was demonstrated by the use of phospho-null mutant variants, $\mathrm{XA} 21^{\mathrm{T} 705 \mathrm{~A}}$ and $\mathrm{XA} 21^{\mathrm{T} 705 \mathrm{E}}$, which are both unable to transduce the XA21mediated immune response or interact with the XA21 binding proteins [147]. After PAMP perception by XA21 (which recognises Xanthomonas oryzae pv oryzae derived sulphonated peptides, [149]), XA21 specifically trans-phosphorylates XB3, which has been shown to 
auto-ubiquitinate in vitro, which may lead to activation of MAPK cascades $[148,150]$. The role of XB3 may be conserved between species in regulating cell death [151]. Additional to phosphorylation and ubiquitination, clearly specific SUMOylation regulation is essential in crops immunity since pathogen effectors pathogenicity by deSUMOylation [140]. The next section will describe in more detail how pathogens hijack the PTM systems for their own benefit, i.e., to evade host defences and gain nutrients to promote pathogen proliferation.

\section{Effectors Disrupt Host PTMs}

The regulation of PTMs is crucial for plant disease resistance to minimise pathogen establishment. Numerous pathogen effectors target PTM machinery, and some effectors themselves act as kinases, SUMO proteases, Ub E3 ligases, etc. to add/ remove PTMs, disrupting the plant defences for pathogen establishment (Table 1). Both aspects of disruption of the PTM-ome show that PTMs are one of the key components for modifying defence against pathogens.

Table 1. Effector examples which regulate host PTM systems.

\begin{tabular}{|c|c|c|c|c|}
\hline Effector & Pathogen & Target/Host & Function & References \\
\hline AvrPtoB & P. syringae & $\begin{array}{c}\text { FLS2, BAK1, CERK1 } \\
\text { (Arabidopsis), FEN (Tomato) }\end{array}$ & E3 ubiquitin ligase & [152-155] \\
\hline AvrPto & P. syringae & $\begin{array}{l}\text { FLS2, EFR (Arabidopsis) } \\
\text { LeFLS2, RIN4 (tomato) }\end{array}$ & Kinase inhibitor & {$[156,157]$} \\
\hline AvrRpm1 & P. syringae & RIN4 (Arabidopsis) & $\begin{array}{c}\text { Induces } \\
\text { phosphorylation }\end{array}$ & [158] \\
\hline AvrB & P. syringae & RIN4 (Arabidopsis) & $\begin{array}{c}\text { Induces } \\
\text { phosphorylation }\end{array}$ & [158] \\
\hline HopF2 & P. syringae & $\begin{array}{c}\text { RIN4, BAK1, MKK5 } \\
\text { (Arabidopsis), MPK6 (Tomato) }\end{array}$ & ADP-ribosylation & [159-162] \\
\hline HopAI1 & P. syringae & $\begin{array}{l}\text { MPK4, MPK6 (Arabidopsis } \\
\text { and tomato) }\end{array}$ & Phosphotheonine lyase & {$[161,163]$} \\
\hline XopAU & Xanthomonas sp. & MKK2 (tomato) & Protein kinase & [164] \\
\hline ХopK & Xanthomonas sp. & OsSERK2 (rice) & E3 ubiquitin ligase & [165] \\
\hline $\mathrm{Xop}_{\mathrm{Xcv85-10}}$ & Xanthomonas sp. & $\begin{array}{c}\text { ERF4 } \\
\text { (tomato) }\end{array}$ & $\begin{array}{l}\text { SUMO protease, } \\
\text { ubiquitin protease }\end{array}$ & {$[140,166,167]$} \\
\hline XopD $\mathrm{D}_{\mathrm{Xcc8004}}$ & Xanthomonas sp. & RGA (Arabidopsis) & SUMO protease? & [168] \\
\hline AvrBsT & Xanthomonas sp. & $\begin{array}{c}\text { SnRK1, ACETYLATED } \\
\text { INTERACTING PROTEIN1 } \\
\text { (ACIP1), proteasomal subunit } \\
\text { RPN8 (pepper) }\end{array}$ & Acetyltransferase & [169-171] \\
\hline AvrXv4 & Xanthomonas sp. & Unknown targets & SUMO protease? & {$[169,172]$} \\
\hline
\end{tabular}

Bacterial pathogens use a type III secretion system to inject effectors intracellularly. Several microbial effectors proteins act as E3 Ub ligases or interact with host E3 Ub ligases to disrupt host ubiquitination and regulation of targets [85]. One well-known case is the Pst type III bacterial effector AvrPtoB which has a C-terminal Ub ligase domain which ubiquitinates PRRs FLS2 and CERK1 causing proteasomal degradation, thereby suppressing defence $[152,153]$. AvrPtoB also causes proteasomal degradation of protein kinase Fen in susceptible tomato plants to prevent ETI activation [154]. In contrast, tomato Pto kinase, in the same family as Fen, interacts with AvrPtoB through binding of two domains of AvrPtoB to evade degradation and activate ETI in resistant tomatoes [155]. AvrPtoB also ubiquitinates and degrades NPR1 to disrupt SA defence signalling [173]. Clearly, pathogen effectors benefit by ubiquitin-mediated proteasomal degradation of immune components to suppress defence responses. 
Effectors also target key immune signalling components. For example, a serine protease effector, HopB1, from P. syringae specifically cleaves the kinase-activated form of BAK1 [174]. Mutations of Arg297 and Gly298 inhibited the BAK1 kinase domain cleavage by HopB1, which explained why related protein SERK5 is not cleaved by HopB1 [174]. BAK1 is targeted by many effectors since it is a coreceptor to several PRRs $[159,175]$. Other effects act to disrupt host phosphorylation; for example, HopAO1 effector from P. syringae is a protein tyrosine phosphatase that dephosphorylates FLS2 and EFR to disrupt PTI [176]. HopAI1 effector inactivates MPK3, MPK4, and MPK6 through the removal of the phosphate group from phosphothreonine [163].

RPM1-INTERACTING PROTEIN 4 (RIN4) can regulate multiple immune signalling pathways and is targeted by four P. syringae effectors: AvrRPM1, AvrB, AvrRpt2, and HopF2 to disrupt RIN4 regulation $[160,177,178]$. Genetically, RIN4 acts as a negative regulator of PTI, but downstream of flg22 detection RIN4 is phosphorylated on S141 to derepress PTI [177]. One example where modification to PTMs leads to changes in disease resistance is with the phosphomimetic RIN4 $4^{\mathrm{T} 166 \mathrm{D}}$ mutant which causes enhanced susceptibility to PstDC3000. RIN4 ${ }^{\mathrm{T} 166 \mathrm{D}}$ plants exhibit inhibition of stomatal defences due to enhanced plasma membrane $\mathrm{H}(+)$-ATPase activity allowing increased pathogen entry through stomata $[177,179]$. It was demonstrated that RIN4 phosphorylation at Thr-166 decreases as part of the defence response downstream of flagellin perception. However, Pst effector AvrB induces RIPK to phosphorylate RIN4 at Thr-166, which antagonises accumulation of the RIN4 S141 phosphorylated form, leading to PTI repression and P. syringae susceptibility (in susceptible genotypes which lack the relevant NLRs) [179,180]. RIN4 is guarded by NLR proteins in resistant genotypes, which recognise RIN4 modifications [178]. Pathogen effectors AvrRPM1 and AvrB induce RIN4 hyperphosphorylation of Thr-166 which reduces the RIN4-ROC1 interaction, which triggers the activation of NLR RPM1 [158,181,182]. AvrRpt2 proteolytically cleaves RIN4, and this is sensed by NLR RPS2 [183]. Activation of the RPM1 or RPS2 NLRs leads to ETI activation leading to HR and Pst resistance in plant genotypes containing these NLR genes [158]. The T166D RIN4 phosphomimetic is sufficient to induce RPM1 activation in resistant genotypes in the absence of pathogen effectors, showing the importance of this specific PTM [184]. Together, this shows that specific phosphorylation patterns are essential for RIN4 to act as a molecular switch to regulate two arms of defence [177]. The importance of PTMs and RIN4 is shown further since RIN4 is conserved in land plants, and S141 and T166 are evolutionarily conserved in RIN4 orthologues [184,185].

RIN4 is an intrinsically disordered protein, except in regions where pathogen-induced posttranslational modifications occur; the regions of disorder allow RIN4 to act as a signalling hub which can bind several different proteins which is important in signal transduction $[179,185,186]$. Substitution of a specific amino acid residue in RIN4 could potentially disrupt one or a few specific protein interactions to boost disease resistance. It was shown using circular dichroism spectroscopy that RIN4 phosphorylation affects protein flexibility; perhaps protein-protein interactions could be manipulated by using PTMs to influence RIN4 structure [179].

Xanthomonas oryzae pv. Oryzae, the causal agent of rice bacterial leaf blight produces the Xanthomonas outer protein K (XopK) effector which has E3 Ub ligase activity and directly ubiquitinates a PTI- related protein, rice somatic embryogenic receptor kinase 2 (OsSERK2), causing its degradation and disruption of PTI [165]. Mutation of the putative ubiquitin-conjugating enzyme (E2) binding site prevented XopK-induced degradation of OsSERK2 and disrupted XopK-dependent virulence [165]. Xanthomonas euvesicatoria (Xe) is the causal agent of bacterial spot disease of pepper and tomato and its effector XopAE also has E3 Ub ligase activity and inhibits plant immunity [187]. Xe type III effector XopAU acts as a protein kinase and disrupts host MAPK signalling through phosphorylation and activation of MKK2 [164].

Xanthomonas type III effector, XopD, has a C-terminal SUMO protease which removes SUMO from target proteins or processes SUMO precursors [140]. Tomato ethylene response 
factor (ERF) SIERF4 is targeted by XopD for deSUMOylation, causing SIERF4 destabilisation and ethylene production inhibition, which is required for ethylene-mediated immunity [166]. Surprisingly, XopD also can act as a SUMO and Ubiquitin isopeptidase [167].

XopD $\mathrm{X}_{\mathrm{Xcc8004}}$, a type III effector of Xanthomonas campestris pv. campestris (Xcc) 8004, a shorter form of the effector XopD which lacks the $\mathrm{N}$-terminal domain, functions as a SUMO protease and this function is necessary to elicit host immune defences [188]. One target of $\mathrm{XopD}_{\mathrm{Xcc8004}}$ deSUMOylation activity is HFR1, which is involved in the repression of plant defence responses.

Additionally, $\mathrm{XopD}_{\mathrm{Xcc} 8004}$ from $\mathrm{Xcc8004}$ interferes with gibberellic acid (GA)-induced GA INSENSITIVE DWARF1 (GID1)-binding to hamper GA-GID1-DELLA complex formation and delay the induced ubiquitination and proteasomal degradation of DELLA protein, a repressor of ga1-3 (RGA). This influences the levels of DELLA proteins to minimise symp-

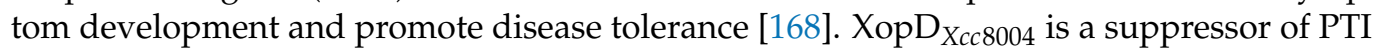
through repression of the flg22-triggered ROS production [168]. The $\mathrm{XopD}_{\mathrm{Xcc} 8004} \mathrm{DELLA}$ interaction might be involved in this PTI suppression as DELLA is involved in SA and JA hormone defence responses [189]. Although $\mathrm{XopD}_{\mathrm{Xcc8004}}$ contains the conserved putative cysteine protease SUMO domain of XopD effectors, deSUMOylation $\mathrm{XopD}_{\mathrm{Xcc8004}}$ was not shown $[168,169]$.

AvrBsT is a Xanthomonas YopJ-like effector, although YopJ-like effectors have homology with SUMO proteases, AvrBsT was identified to have acetyltransferase activity [170]. In pepper plants, AvrBsT targets proteasomal NON-ATPASE SUBUNIT 8 (RPN8) potentially to disrupt proteasomal function and targets energy sensor Sucrose nonfermenting 1 (Snf1)related kinase (SnRK1) to disrupt the HR immune response elicited by effector AvrBs1 in resistant pepper plants [169,171]. AvrXv4 is another Xanthomonas YopJ-like effector which decreases the accumulation of SUMO-protein conjugates in Nicotiana benthamiana and pepper, in planta [172]. It may be that AvrXv4 has SUMO proteases activity, but it is not yet proven [169].

Fungal and oomycete effectors also act to affect the host's ubiquitination system to evade immunity, for example, the Phytophthora infestans effector AVR3a, by modifying and stabilising host E3 Ub ligase CYS, MET, PRO, AND GLY PROTEIN 1 (CMPG1) to prevent the usual CMPG1 proteasomal degradation and prevent cell death [190]. The Magnaporthe oryzae (the causal agent of rice blast) fungal effector AvrPiz-t targets the RING E3 Ubiquitin Ligase AVRPIZ-T AND AVRPIZ-T INTERACTING PROTEIN 6 (APIP6) for degradation to suppress PTI in Rice [191].

The numerous effectors acting to disrupt immunity and promote pathogen establishment by altering plant PTMs demonstrate how crucial specific PTMs are to host resistance to pathogens. This ascertains that pathogen effectors disrupt PTMs in various ways, highlighting that precise regulation of PTMs is important in defence to prevent pathogen establishment.

\section{Growth-Defence Trade-Offs}

Plants tightly control the balance between growth and defence in order to optimise fitness and overcome stress [192,193]. Growth-defence trade-offs occur as plants restrict growth when activating their defence responses [194]; this could be to reallocate the plants' limited resources when challenged by stress. Although in many cases, it is thought that resources are not a limiting factor, growth-defence trade-offs result from the careful regulation of complex signalling networks controlling plant metabolism [192,195-198].

SnRK1 and TOR (target of ramamycin) are energy sensors, act as global master regulators of metabolism, and play a dynamic and important role in the growth-defence balance $[199,200]$. SnRK1 and TOR are key in responding to biotic stress for plant survival (Figure 3) [201]. SnRK1 and TOR are protein kinase complexes which largely work antagonistically, and their crosstalk is evolutionarily conserved [198,202]. Typically TOR is activated in nutrient-rich conditions and promotes growth [203]. SnRK1, SnRK2, and SnRK3 subfamilies all have roles in promoting defence [204], but SnRK1 is the most promi- 
nent in the global regulation of metabolism in response to energy status [205]. SnRK1 is activated in response to energy depletion often occurring in stress conditions to restore energy homeostasis [206-211] (Figure 3).

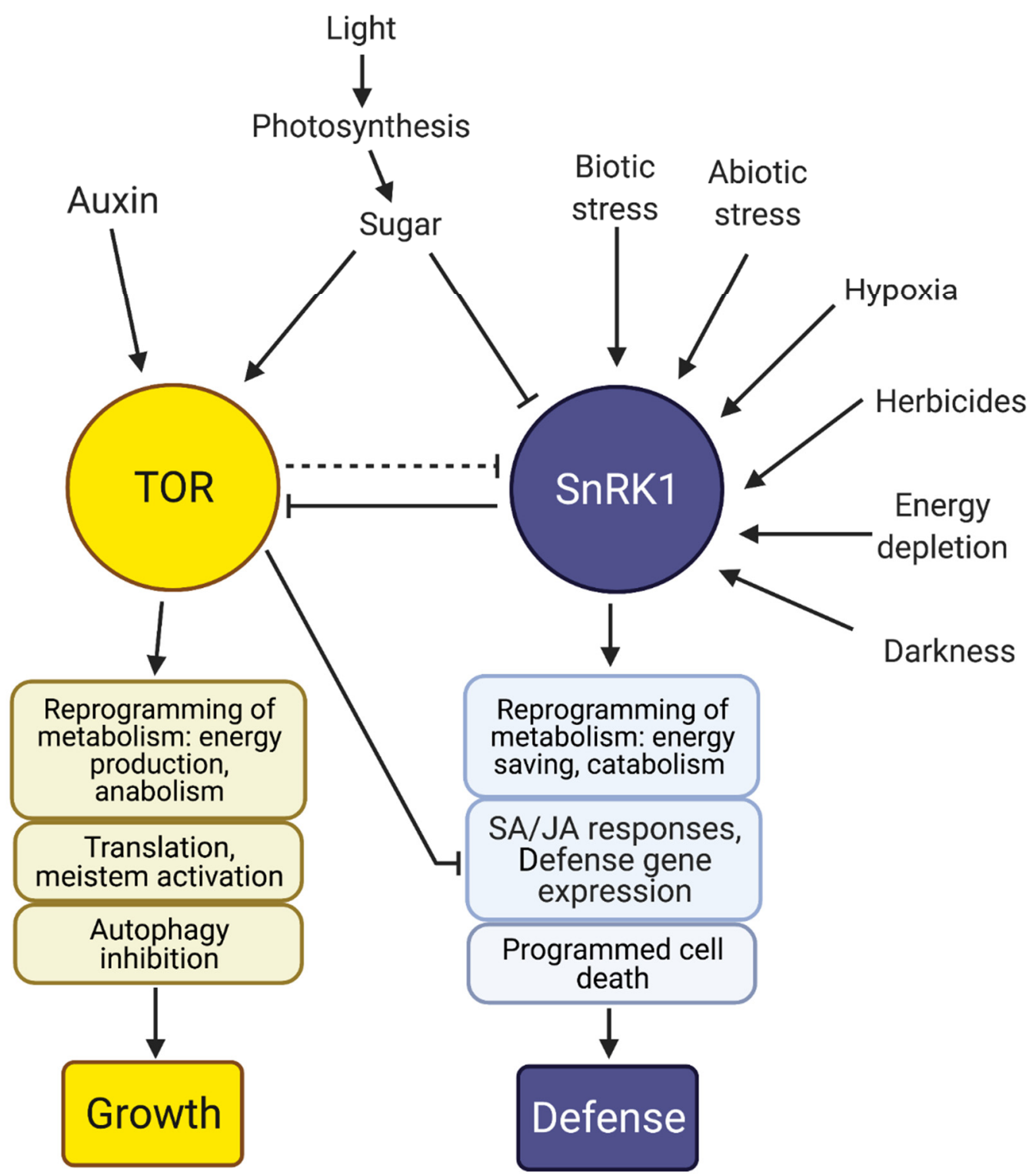

Figure 3. A simplified model of SnRK1-TOR growth-defence regulation. Kinases Sucrose nonfermenting 1 (Snf1)-related kinase (SnRK1) and target of ramamycin (TOR) are master regulators which sense energy status and work antagonistically to reprogramme metabolism through phosphorylation of diverse targets. TOR is active in nutrient-rich conditions to promote translation and growth while inhibiting autophagy. SnRK1 is activated in times of energy depletion often caused by stress, operates to promote defence responses, and suppresses growth. SnRK1 phosphorylates and inactivates TOR directly to limit growth and promote autophagy. TOR inhibits SnRK1 outputs indirectly. Solid lines indicate direct interactions, dashed lines indicate indirect interactions.

PTMs are critical in the activities and regulation of SnRK-TOR growth-defence balance. SnRK1 and TOR phosphorylate targets to trigger transcriptional and metabolic reprogramming [212-216]. SnRK1 and SnRK2 repress TOR as part of their growth suppression by phosphorylating the regulatory-associated protein of TOR (RAPTOR) component; this regulation is evolutionarily conserved (Figure 3) [202,217]. SnRKs and TOR are integrated with hormone signalling, which can regulate growth [218]. For example, SnRK1 is a negative regulator of auxin-mediated primary root growth by activating SHORT HYPOCOTYL 
2/INDOLE ACETIC ACID 3 (SHY2/IAA3) transcription [219], whereas auxin activates TOR signalling to promote growth [220].

SnRK1 is phosphorylated and activated by SnAK1 and SnAK2 (SnRK1-activating kinases), also known as geminivirus Rep-interacting kinases 1 and 2 (GRIK1 and GRIK2), which are regulated during plant development and geminivirus infection [221]. SnAK1 and SnAK2 have been shown to phosphorylate and activate the Arabidopsis SnRK1.1/SnRK1 $\alpha 1 /$ KIN10 catalytic subunit on conserved residue Thr ${ }^{175}$. Phosphatases ABA INSENSITIVE 1 (ABI1) and TYPE 2A PROTEIN PHOSPHATASES (PP2CA) dephosphorylate and inactivate SnRK1 to regulate its activity [222].

SnRK1 provokes metabolic reprogramming under pathogen attack (Figure 3), which promotes broad disease resistance and plant fitness at the expense of growth, whilst TOR promotes growth and proliferation and suppresses defence-related genes, compromising immunity [198]. SnRK1 gain- and TOR loss-of-function plants tend to be more resistant, whereas TOR gain- and SnRK1 loss-of-function plants tend to be more susceptible; this is the case for viruses, bacteria, fungi, and oomycetes [198,223,224]. To support this, it was revealed that OsSnRK1a overexpression increased resistance against both (hemi)biotrophic and necrotrophic pathogens but suppressed normal growth and development, while OsSnRK1a silencing in RNAi lines increased susceptibility [225]. OsSnRK1a overexpression positively affected the SA pathway and boosted the JA defence to promote defence-related gene expression. TOR reduces plant defences by antagonising the action of SA and JA and suppresses defence-related genes [224,225]. SnRK1 is capable of phosphorylating viral proteins such as Rep to impair viral replication [226]. This highlights how significant SnRK1 is in defence responses. The regulation of SnRK1 and TOR can differ in different tissues $[227,228]$.

SnRK1 is involved in enhancing immunity in a variety of ways through phosphorylation of targets. SnRK1 phosphorylates WRKY3, a repressor of immunity, to promote its proteasomal degradation, enhancing resistance to powdery mildew [229]. SnRK1 phosphorylation at Ser83 and Ser112 triggers WRKY3 degradation, and therefore, S83 and S112 mutated versions of WRKY3 were more stable than the wild-type protein. Homologue SnRK2.8 has a major role in regulating SAR, as its phosphorylation of monomeric NPR1 by SnRK2.8 at Ser-589 and possibly Thr-373 facilitates NPR1 entry into the nucleus [230]. Although SnRK2.8 activation is independent of SA, NPR1 monomerisation is triggered by SA-triggered redox changes $[231,232]$. SnRK1 is required for the induction of the AvrBs1-specific HR and programmed cell death (PCD) [171].

Several pathogens disrupt the SnRK1-TOR balance between growth and defence; for example, SnRK1 in rice is targeted by Xanthamonas effector AvrBsT (Table 1), showing that pathogens can disrupt this key plant defence regulator [171]. Likewise, viral suppressors of RNA-silencing proteins AL2 and L2 inhibit SnRK1 activity [208]. SnRK1 stability is also impacted by pathogens; the effector from Fusarium graminearum, the causal agent of Fusarium head blight, orphan secretory protein 24 (Osp24), accelerates the degradation of TaSnRK1 $\alpha$ by facilitating its association with the ubiquitin-26S proteasome [233]. Similarly, the TOR pathway can be activated to benefit pathogens; for example, the cauliflower mosaic virus TAV effector protein binds to TOR, promoting its activity and leading to RIBOSOMAL PROTEIN S6 KINASE (S6K1) phosphorylation, which promotes translation reinitiation and viral replication [234]. However, favouring TOR pathway activity is not always beneficial to pathogen's activity; the Ralstonia solanacearum effector AWR5 inhibits TOR signalling, perhaps to allow autophagy to proceed [235]. SnRK1 acts upstream of TOR as a positive regulator of autophagy in Arabidopsis, and TOR inhibits autophagy in nutrient-rich conditions through TOR-induced phosphorylation of AUTOPHAGY RELATED 1 and 3 (ATG1 and ATG13) proteins [236]. When TOR is inhibited, autophagy proceeds [237]. Selective autophagy cooperates with the ubiquitin-proteasome system to contribute to immunity but unregulated autophagy could benefit pathogens [238,239].

In addition to phosphorylation by SnRK1 and TOR kinases, regulation of growth-vsdefence also depends on SUMOylation, in conjunction with ubiquitination. The SnRK1 
complex is SUMOylated at multiple positions by SIZ1 [240]. SUMOylated SnRK1 undergoes ubiquitination and proteasomal degradation to modulate SnRK1 signalling in Arabidopsis, whereas siz1-2 null mutant and siz1 catalytically inactive mutant show accumulation and hyperactivation of SnRK1. It was shown that SnRK1 triggers its own SUMOylation and ubiquitination-mediated degradation as part of a negative feedback loop; this ensures SnRK1 signalling is activated at the precise level, avoiding hyperactivation of defence responses. The dependence on SnRK1 activity controlling its own degradation was confirmed by the finding that phospho-inactive SnRK $1 \alpha 1$ variants were not degraded as normal, but normal degradation of SnRK1 $1 \alpha 1$ occurred in SnRK $1 \alpha 1$ "SUMO mimetic mutants" mimicking the SUMOylated from of SnRK1 through translational fusion [240,241].

Downstream of SnRK1, via the domain of the unknown function (DUF)581-2, two DELLA proteins, gibberellic-acid insensitive (GAI) and RGA, were shown to be stabilised (Figure 4) [242]. DELLAs are suppressors of growth and act to suppress GA-responsive genes and GA biosynthetic genes and promote negative GA signalling components to maintain GA homeostasis [243]. Arabidopsis contains five DELLA protein genes (RGA, GAI, RGA-Like1 (RGL1), RGL2, and RGL3) which have some overlapping functions in repressing GA responses [242]. Stress signals inhibit the degradation by GA, including PAMP elicitor flg22 [244]. DELLAs are regulatory signalling hubs which integrate environmental signals and are regulated mostly at the post-translational level with SUMOylation, ubiquitination, and phosphorylation as critical PTMs of DELLAs (Figure 4) [245-247]. GA, a growth-promoting phytohormone, relieves the DELLA-mediated repression of genes through binding of GA to its receptor GID1 which triggers ubiquitination and proteasomal degradation of DELLAs [248-254].
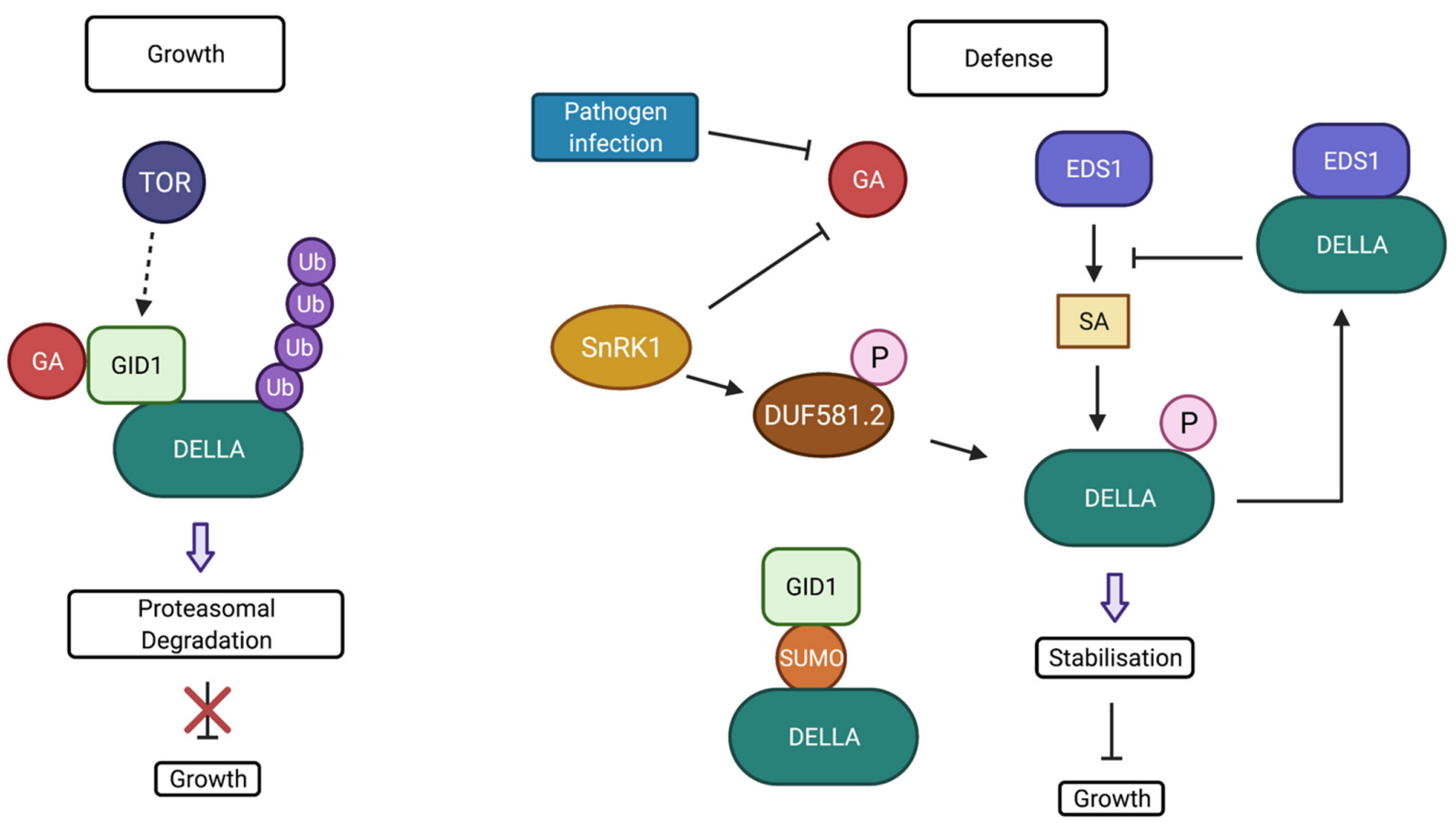

Figure 4. DELLA interactions with PTMs in growth and defence. When gibberellic acid (GA) accumulates, it binds to GA INSENSITIVE DWARF1 (GID1) which then binds to DELLA, triggering DELLA ubiquitination and proteasomal degradation and allowing GA-responsive gene expression and growth. DELLA is stabilised in various ways to promote defence and restrict growth. In defence, GA levels are reduced which reduces GA-mediated DELLA degradation. DELLA is stabilised by phosphorylation. Independent of GA, DELLA is stabilised by SUMOylation which blocks GID1 degradation on unSUMOylated DELLA. SnRK stabilises DELLA through intermediate protein DUF581-2. DELLA forms a negative feedback loop to control SA accumulation. P, phosphate group. S, SUMO. Ub, Ubiquitin. Solid lines indicate direct interactions; dashed line indicates suggested positive interaction. 
SnRK1.1/SnRK1 $\alpha 1 /$ KIN10 represses GA biosynthesis by phosphorylating and stabilising transcription factor FUS3 [255-257]. By contrast, TOR may promote GA signalling as mutants lacking in TOR component protein RAPTOR1B have decreased GID1 expression and increased levels of DELLA protein RGA suggesting TOR may promote GA signalling [258]. Interestingly, around $28.6 \%$ of the genes induced by SnRK1.1 were also upregulated by DELLA protein RGA [259].

Stress signals, including pathogen infection, stabilise DELLA proteins preventing ubiquitin-mediated degradation which contributes to growth inhibition [189,244,245]. DELLAs cause susceptibility to biotrophs and resistance to necrotrophs by altering the balance of salicylic acid vs. jasmonic acid signalling in Arabidopsis [189]. In contrast to Arabidopsis, rice DELLA Slender Rice1 (SLR1) promotes resistance to (hemi)biotrophic but not necrotrophic rice pathogens [260]. Cassava (Manihot esculenta) MeDELLAs were shown as positive regulators of disease resistance against cassava bacterial blight [261]. This shows that DELLAs are important positive regulators of defence in diverse species.

SUMOylation of DELLA occurs in stress, and the SUMOylated DELLA binds to GID1 via its SUMO interacting motif (SIM). This occurs independently of GA, which sequesters GID1 to prevent GA degradation (Figure 4) [262,263]. This leads to an accumulation of non-SUMOylated DELLA which causes repression of GA responses and growth restriction. Some phenotypes of Arabidopsis SUMO protease mutant ots1ots2 are mediated through DELLA since the knockout of a DELLA protein restores the ots1ots2 double mutant background to the WT phenotype [264]. Higher DELLA levels accumulate in the ots1ots2 double mutant, which shows that OTS1/2 deSUMOylate DELLA, which destabilises DELLAs. However, DELLA stabilisation causes high DELLA levels and reduced fertility [264]. Rice DELLA SLR1 also undergoes SUMOylation, which alters its interaction with specific transcription factors to improve abiotic stress tolerance [265]. There is a suggestion that SLR1 SUMOylation may attenuate the penalty of salt stress tolerance on plant yield [265], with the goal of maintaining yield and disease resistance under pathogen stress in rice, which would be interesting to explore. In addition, mutation of the SIM site in GID1 in rice or Arabidopsis could be manipulated to fine-tune DELLA degradation [263]. DELLA stability is also increased by phosphorylation (Figure 4); in rice, EARLIER FLOWERING 1 (EL1) stabilised SLR1 [266]. In Arabidopsis, it was shown that protein phosphatase dephosphorylates DELLA promotes GA-induced degradation [267].

DELLA protein RGL3 positively regulates JA-mediated resistance to the necrotrophs [268]. DELLAs promote JA defence responses by competing with MYC2 for binding to JAZ proteins; this relieves MYC2 from JAZ suppression to allow MYC2-dependent JA responses to contribute to the balance of growth and defence $[269,270]$. Similarly to protein JA responses, MdSnRK1.1 phosphorylates MdJAZ18 protein in apple to facilitate its 26S proteasome-mediated degradation which is likely relevant in defence [271]. Intriguingly, SnRK1 mediates proteasomal binding of a plant SCF ubiquitin ligase which can modulate JA responses. Pathogen infection stabilises DELLA proteins RGA and RGL3 to restrict growth in a partially EDS1-dependent manner [244]. However, DELLA also directly interacts with EDS1 to together decrease SA production as part of a negative feedback mechanism to modulate the SA accumulation and to prevent excessive defence response (Figure 4) [244]. Clearly, DELLAs alter the balance of salicylic acid vs. jasmonic acid signalling, and DELLA regulation by PTMs is important in growth-defence balance [189].

There may be potential to control specific elements of this growth-defence network through manipulation of SnRKs/TOR phosphorylation targets or through other interacting PTMs, to uncouple antagonistic activities in growth and defence to yield [272]. Beyond SnRK1 vs. TOR antagonism, several other components have antagonistic pathways to balance growth and defence; for example, the MAPK cascade MEKK1-MKK1/2-MPK4 negatively regulates plant cell death and immunity downstream of PAMP activation of PRRs, whilst MPK3/ 6 cascades positively regulate immunity [61].

Plants mitigate growth-defence trade-offs through methods including inducible tissuespecific defence and priming [273]. Defence pathways can be "primed" for faster and 
stronger activation to subsequent pathogen attacks, and primed states can be transmitted to offspring [274]. Priming by elicitors such as flg22 and chitin could be mediated by manipulating PTMs on components such as NPR1. MAPKs could potentially induce a primed state, but more investigation is necessary [275]. Changes in phosphorylation could potentially change the growth-defence balance after priming. Using priming agent B-AMINOBUTYRIC ACID (BABA), a mutation in eIF2 $\alpha$-phosphorylating GENERAL CONTROL NON-DEREPRESSIBLE 2 (GCN2, also known as PBL27) kinase did not affect BABAinduced immunity, but relieved BABA-induced growth repression [276]. Interestingly, TOR blocks the action of GCN2 to promote translation, since GCN2 inhibits translation initiation upon sensing the uncharged transfer RNAs that accumulate during amino acid limitation to maintain amino acid homeostasis in nitrogen deficiency [277]. GCN2 function might be conserved between plant species [206].

Hormone metabolism must be tightly controlled in the right situation, with most plant hormones being involved and interacting in immunity [278]. SA and JA are typically antagonistic, although SA and JA can occasionally act synergistically as well [279]. Several hormones control the balance between growth and defence: auxin and SA are antagonistic, with auxin promoting growth, and SA promoting defence $[280,281]$. JA inhibits growth as part of defence [282], and crosstalk exists between brassinosteroid, auxin, and gibberellin signalling.

Inhibition of photosynthesis is frequently observed as part of the defence response; reducing photosynthesis may starve biotrophic pathogens of nutrients [283]. However, mutant jazQ (jaz quintuple) phytochromeB (phyB) plants grow and defend well simultaneously; the whole-plant photosynthetic rate in jazQ phyB plants was similar to WT, showing that perhaps manipulation of plant proteins can alter the balance of growth and defence and that hormone pathways are important.

BR-mediated growth can antagonise innate immune signalling [284]. Yet, treatment with Brassinolide (BL), the main brassinosteroid, induced resistance to a range of diseases in tobacco, and resistance to rice blast and bacterial blight in rice [285]. Additionally, BRs can increase resistance to the cucumber mosaic virus [286]. BR treatment increases resistance to necrotrophs and insects via increased JA response [287]. BAK1 is involved in PTI and in brassinosteroid signalling in development, whereas BIK1 positively regulates plant immunity, yet negatively regulates BR signalling [288]. As mentioned in a previous section, BAK1 mutants T450A and C408Y both show severe defects in immune defence but normal growth phenotype, proving that the phosphorylation patterns of RLK partners by BAK1 could selectively regulate multiple BAK1-dependent pathways [46]. Interestingly, the gain-of-function bak $1^{\text {elg(elongated) }}$ protein results in increased BR signalling and impaired response to flagellin [289]. Further gain-of-function mutations could potentially increase defence signalling without affecting growth, although BRs antagonise immunity without BAK1 [284].

Significantly, IDEAL PLANT ARCHITECTURE1 (IPA1)/WEALTHY FARMER'S PANICLE (WFP)/Rice SQUAMOSA PROMOTER BINDING PROTEIN-LIKE 14 (OsSPL14) was identified to enhance yield-related growth as well as disease resistance, and PTMs are crucial to its regulation [290,291]. OsSPL14 positively regulates panicle branching and grain numbers per panicle in the reproductive stage and negatively controls shoot branching (tillering in rice) in the vegetative stage, by regulating the expression of TEOSINTE BRANCHED1 (TB1) and DENSE PANICLE 1 (DEP1) [290,292]. Phosphorylation and ubiquitination are necessary for OsSPL14 activity and regulation. OsSPL14 is phosphorylated at the serine163 residue following pathogen infection, which changes its DNA binding specificity to activate the expression of WRKY45, which then enhances disease resistance [291]. OsSPL14 returns to the nonphosphorylated state within $48 \mathrm{~h}$ postinfection to activate genes related to growth and high yield [291]. A RING-finger E3 Ub ligase, IPA1 INTERACTING PROTEIN1 (IPI1), carries out tissue-specific ubiquitination which promotes the degradation of OsSPL14 in panicles, whilst stabilising OsSPL14 in shoot apexes [293]. This is caused by IPI1 ubiquitinating OsSPL14 with different polyubiquitin chains, adding K48-linked 
polyubiquitin chains in panicles for OsSPL14 degradation, and K63-linked polyubiquitin chains in the shoot apex to control plant architecture [293]. The natural ipa1-1D allele has a nucleotide substitution at the OsmiR156 target site, allowing it to resist microRNA transcript cleavage, resulting in higher expression in panicles [294,295]. This allowed a $10 \%$ yield increase without blast disease, up to $40 \%$ with blast disease than controls in field trials [291]. Overexpression of IPA1/OsSPL14 also enhanced disease resistance against bacterial blight but a reduction in yield was observed; however, the yield was restored when expressing OsSPL14 with the pathogen-inducible promoter of OsHEN1 [296]. This phosphorylation switch to defence gene expression which is reversed after $48 \mathrm{~h}$ is essential for OsSPL14 function, combined with tissue-specific ubiquitination controlling stability. This K48 vs. K63 ubiquitin linkage needs more investigation to investigate how widespread this regulation is, along with its potential for manipulation.

SPL protein homologues have different functions but share a highly conserved DNAbinding domain (SQUAMOSA-PROMOTER BINDING PROTEIN (SBP) domain) and a conserved serine residue which functions as a phosphorylation site [297]. Phylogenetic analysis identified that SPL subgroup III contained orthologous SPL proteins, including OsSPL14 (IPA1), OsSPL7, and OsSPL17 from rice; ZmSBP8, ZmSBP30, and ZmSBP6 from maize, and AtSPL9 and AtSPL15 from Arabidopsis, which all perform a similar function in regulating vegetative/reproductive branching in various plant species [298-300]. In AtSPL9-overexpressing plants, there was a greater accumulation of ROS and transcripts of basal salicylic acid signalling pathway genes, compared with wild-type Col-0 plants; thus, AtSPL9 could have a role in disease resistance [301]. These maize SPL proteins could be investigated to discover if the phosphorylation-ubiquitination control has any roles in disease resistance and growth, similar to OsSPL14 (Supplementary Figure S1).

To improve plant disease resistance, optimising the balance between growth and defence is important. Growth trade-offs may not be inevitable with increased immunity and disease resistance with the right strategy [195,197]. It is critical to improve disease resistance to reduce pathogen colonisation and crop losses whilst minimising compromises in growth and reproduction to maintain and maximise yield in a dynamic environment. Alteration of specific protein PTMs could potentially promote certain interactions to allow enhanced disease resistance and growth simultaneously whilst allowing growth at the right times; methods will be explored in the next section.

\section{Exploiting PTMs to Produce Disease-Resistant Crops}

Crop selection is based on yield-related traits; the diversity of disease resistance genes in most crop plants today has been reduced as a consequence [302]. NLR genes have been used widely but are often not durable as a result of pathogen evolution. The pyramiding of NLR genes can be a solution to durability but can cause reduced growth and yield in the absence of pathogen infection [296]. NLR gene introduction can lead to excessive HR response, inappropriate activation of defence genes, or regulation of ROS [65,303-305]. There needs to be more research into durable disease resistance without compromising yield. Several potential advances need testing in the future. Genome editing, specifically the clustered regularly interspaced short palindromic repeats/CRISPR-associated protein (CRISPR/Cas) system, has the ability to generate knockouts of, for example, "susceptibility genes"; however, this can have detrimental effects if a protein is multifunctional [306]. The use of CRISPR/Cas and knowledge of PTMs enable the change in critical effector interaction residues of pathogen targets to prevent pathogen PTM attachment and methods of pathogenicity (Figure 5). 


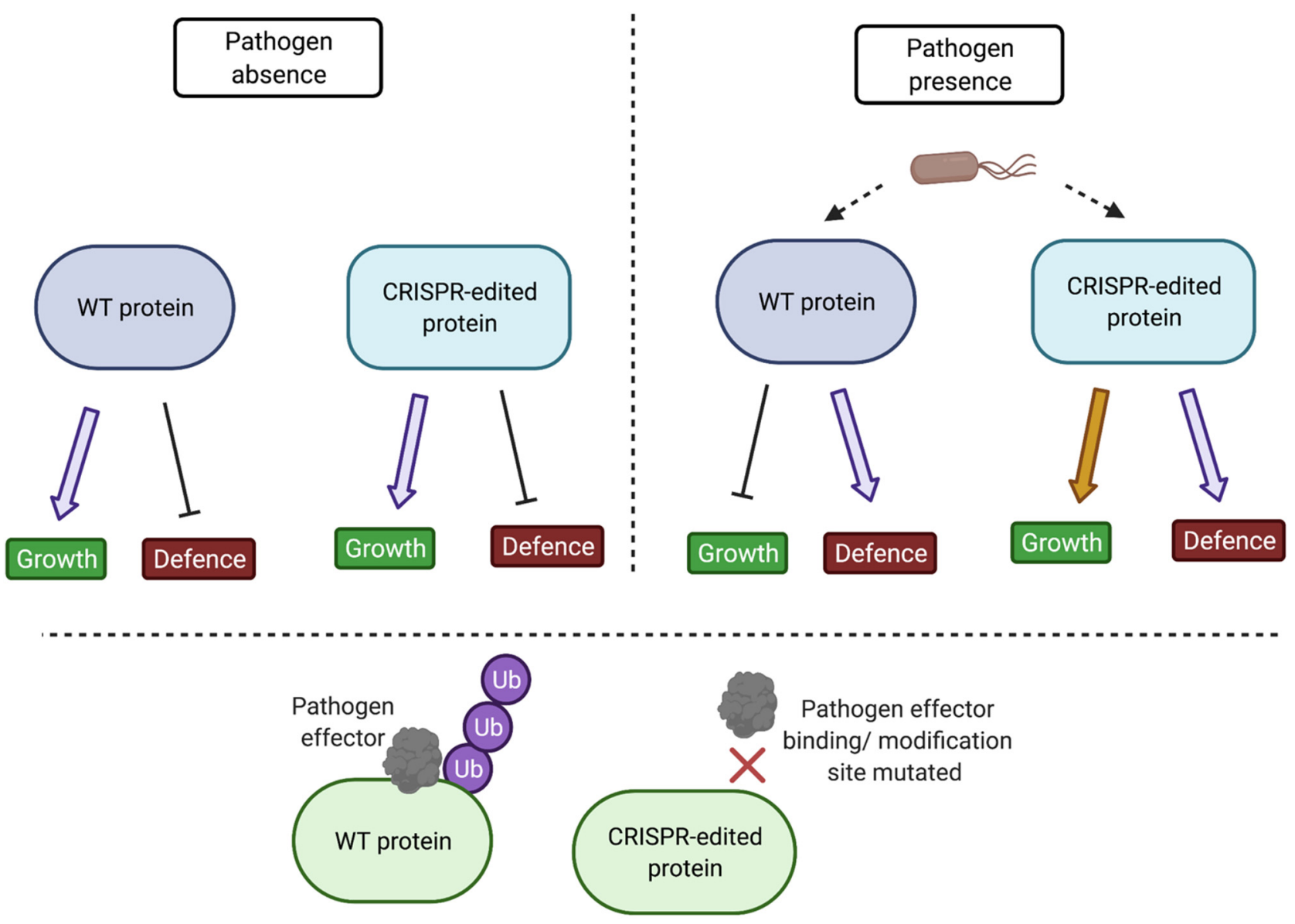

Figure 5. Model for improving disease resistance centring on PTMs. Genome-edited proteins giving rise to amino acid substitutions may confer disease resistance by allowing the protein to evade pathogen effectors, or through optimising growth-defence trade-offs to avoid excessive growth restriction in defence by controlling precise protein-protein and protein-PTM interactions.

Manipulation of PTMs can be exploited to increase plant disease resistance; for example, in rice, overexpression of the phosphomimetic version of OsWRKY53 enhanced resistance to rice blast, compared to overexpression of the WT version of OsWRKY53 [307]. The MAPK cascade OsMKK4-OsMPK3/OsMPK6, which functions in the response to fungal PAMPs in rice, phosphorylates the SP (serine-proline) cluster of OsWRKY53 in vitro and likely in vivo [307]. The SP cluster is a highly conserved cluster among several group-I WRKY proteins in higher plants, and the phosphomimetic version of OsWRKY53 has all six Ser residues in the SP cluster substituted for Asp (OsWRKY53SD) which mimics phosphoserine [308]. Coexpression of OsWRKY53 with a constitutively active OsMKK4 increased OsWRKY53 transactivation activity in an SP cluster-dependent manner; furthermore, the OsWRKY53 phosphomimetic had enhanced transactivation activity compared to the WT version. These together suggest that phosphorylation of the SP cluster increases transactivation activity [307]. Interestingly, phosphorylation of OsWRKY53 by OsMPK6 did not alter its DNA-binding activity to W-box elements. The phosphomimetic OsWRKY53SD-OX rice plants had enhanced defence to rice blast and high activation of defence genes, including PR genes, compared to OsWRKY53-OX plants. Additionally, it was found that plants overexpressing the phosphomimetic OsWRKY53 have normal growth and development. This strategy has potential for crop production; however, yield tests, followed by large-scale field trials, would need to be carried out. PTM mimics are not perfect and therefore could have unexpected effects [307].

PTMs that a protein undergoes depends on protein sequence as well as other modes of regulation. Therefore, genetic sequence variants influence the protein sequence and 
hence PTMs. Sequence variants can be associated with disease resistance through PTMs. SNP databases are starting to increase particularly for rice, and there are trait-associated SNP databases for stress-related SNPs $[309,310]$. Prediction of how SNPs may influence PTMs is improving, which could be useful to predict protein interactions, enzyme activity, and protein turnover of different gene alleles, as well as to direct hypotheses, find out the specific mechanisms, and understand potential pleiotropic effects [311]. In animals, disease-associated PTM-SNPs have been identified and assembled into a database; thus, a similar idea could be formed for crop plants [312,313].

Biotechnological advances allow a proteome-wide approach for discovery, as well as a rational, targeted approach in the production and testing of new crop lines. Biotechnological approaches also extend beyond the reliance on existing natural allelic variations present in sexually compatible germplasm [314]: the application of genetic engineering is one of the leading technological advances in recent decades [315]. Genetic engineering has typically involved knockout or overexpression of genes to modify defence response pathways, but this can cause yield and/or quality trade-offs. There is the challenge to avoid these growth and yield trade-offs with improvements in disease resistance [316]. Finally, genome editing, in particular CRISPR/Cas, has become the most important biotechnological tool which had great potential and is recently being increasingly utilised [317].

Base editors or prime editors, as part of the CRISPR/Cas system, will be useful to modify critical PTMs of defence-related proteins through modification of nucleotides to alter specific amino acids. Alteration of amino acids could increase the stability of PTMs or abolish PTMs, thus altering protein function, interaction, and downstream responses to produce disease-resistant plants and crops (Figure 5). For example, alteration of ubiquitin site could increase the stability of immune signalling components, so long as they are inactive until activated by subsequent phosphorylation/SUMOylation at the appropriate time to avoid growth penalties.

Base editors could prove useful for making amino acid substitutions in defencerelated proteins. Base editing does not involve double-strand breaks and features a Cas 9 nickase (Cas9n) (or catalytically inactive Cas9) fused to nucleoside deaminases [318-320]. Cytosine base editors (CBEs) and adenine base editors (ABEs) currently enable four types of nucleotide conversions ( $C$ to $T, T$ to $C, A$ to $G$, and $G$ to $A$ ) [321]. Recently using engineered Cas9 variant, Cas9-NG, fused to base editors, rice BR-SIGNALING KINASE 1 (OsBZR1) gain-of-function mutants carrying $C>T$ conversions were successfully identified. Additionally, A > G conversions were induced in OsSERK2 with a 9-40\% success rate [321]. The $\mathrm{A}>\mathrm{G}$ conversion targeted phosphorylation site in OsSERK2, which is expected to change downstream signalling in development or defence [322].

The C > T conversions carried out in OsBZR1 caused a P234L substitution, which is predicted to produce the ortholog of the stabilising gain-of-function Arabidopsis allele, $b z r-1 d$. Plants with the $b z r-1 d$ allele have increased BZR1 dephosphorylation, enhanced BR signalling, and BR-mediated growth $[323,324]$. This BZR1-1D mutation has been reported to increase tomato quality [325] and the bil1-1D/bzr1-1D allele increased resistance to thrips in Lotus japonicus, which cause damage and transmit disease possibly through increased JA levels [287]. BZR-1D allele could potentially balance growth and yield since increased BR-signalling leads to increased seed production [326]. However, disease resistance must be maintained despite the increased BR signalling, potentially by using combinations of promoters, coding sequences, vectors, and genotypic backgrounds, which is complex and thus needs more research [324].

Editing OsSERK2 is promising for balancing defence and yield, as OsSERK2 regulates brassinosteroid-mediated growth and PRR immune signalling [322]. Specific phosphorylation sites in AtBAK1 mediate interactions and responses; thus, it is likely this is the case in crops [46]. OsSERK2 positively regulates immunity mediated by XA21, XA3, and OsFLS2 which are structurally similar receptor kinases [322]. OsSERK2 is required for rice Xa21mediated resistance to Xanthomonas oryzae pv. oryzae (Xoo) and to the hemi-necrotrophic fungus Magnaporthe oryzae. OsSERK1 (OsBAK1) has greater similarity to AtBAK1 and is 
important in plant growth and development, but OsSERK1 is not required for rice immunity to Xoo or M. oryzae [327]. OsSERK2 undergoes bidirectional transphosphorylation with XA21 in vitro and forms a constitutive complex with XA21 in vivo, unlike BAK1's interaction with FLS2 and EFR which occurs after ligand binding, and BAK1 carries out transphosphorylation rather than FLS2 or EFR [322]. The phosphorylation pattern effects must be explored further.

Prime editing is an exciting new tool which allows the introduction of all mutation types, including insertions, deletions, and all putative 12 types of base-to-base conversions [328]. Prime editors, which are CRISPR-Cas9 nickase-reverse transcriptase fusions programmed with prime editing guide RNAs (pegRNAs), can edit bases without donor DNA or double-strand breaks and have been demonstrated in rice and wheat cells [328,329]. Mutations identified or predicted to improve disease resistance can be achieved in crops with prime editing techniques, although efficiency needs improvements. Ser/Thr phosphorylation sites, Ubi, and SUMO lysines are replaced by alanine to disrupt the site, but also point mutations elsewhere in the protein can alter protein structure or interactions and therefore function $[46,118,291]$. Substitution of the important residues surrounding a PTM site, rather than the attachment amino acid site, could weaken or strengthen PTM attachment, rather than completely abolishing it. The substitutions could alter the strength of the enzyme-substrate interactions or other signalling interactions [56,146,330].

One strategy for improved disease resistance could be to prevent effector posttranslational modification; genome editing could be utilised to modify critical amino acid residues targeted or induced by pathogen effectors to undergo PTM attachment (Figure 5) [185,306]. For example, base editing or prime editing could be used to substitute critical PTM sites in RIN4 to boost immunity in crop plants. For instance, one way could be to modify the conserved Thr-166 phosphorylation site to overcome the susceptibility to pathogen effectors including AvrB and Rpst2. Thr-166 counteracts the flg22 induced phosphorylation of S141 to suppress defence when it is activated: the T166A phospho-null RIN4 mutant still maintained the flg22-activated suppression of Pseudomonas syringae pv. tomato strain DC3000 proliferation [177]. Similarly, T166A substitution may not lead to overactivation of defence since RIN4 is a negative regulator of PTI until S141 phosphorylation causes derepression of PTI $[177,185]$.

Pathogen-inducible promoters such as OsHEN1 [296], OsCYP76M7 [331], and TBF1 (TL1-BINDING FACTOR) [332] may prove useful to overexpress PTM machinery enzymes including kinase/phosphatases and SUMO proteases that are positive regulators of immunity, specifically under stress, or in specific tissues to boost disease resistance at the time needed to avoid growth cost associated with constitutively activated defence responses, for example, to enhance SnRK1 expression specifically in stress affected regions or reduce expression of PUB12/13 specifically in stress to relieve the autoimmunity of the pub13 mutant [86]. CRISPR/Cas techniques can be utilised for sequence replacements using HOMOLOGY DIRECTED REPAIR (HDR) to replace or edit a specific promoter for stressinducible or tissue-specific genes $[333,334]$. However HDR sequence replacement has low efficiency in plants; therefore, efficiency needs to be improved.

Catalytically inactive or dead-Cas9 (d-Cas9) driven by an inducible or tissue-specific promoter could prevent transcription of particular genes of PTM machinery to boost immunity with pathogens detected in a particular cell type. This could reduce transcription of a PUB ubiquitin ligase, SUMO protease, specific kinase/phosphatase to control specific PTM attachment/removal to reduce specific defence protein activation/inactivation or turnover during the pathogen stress [335]. SUMO proteases and ubiquitin ligases provide specificity in their respective pathways, and therefore, modification of these enzymes expression could provide a more specific response [48,336-338].

The use of genome editing speeds up crop breeding for specific sequences that generate beneficial traits. Gene editing can also introduce new edits not found within reproductively compatible germplasm, but unlike genetic engineering, the transgene for the CRISPR construct can be segregated out after stable integration or can be delivered transiently [339]. 


\section{Conclusions and Perspectives}

All aspects of plant defence use PTMs; the significance of PTMs is also clear since pathogen effectors disrupt PTM regulation as part of their virulence. Strategies predicted to increase disease resistance include the substitution of specific amino acid residues to stabilise or destabilise the formation of specific PTMs for precise control of protein function (Figure 5). One challenge will be to improve the efficiency of CRISPR/Cas techniques such as base editors and prime editors which, at present, show low efficiency. The growthdefence balance is critical-favouring defence does not necessarily mean that growth must be penalised if a careful manipulation of PTMs to control protein interactions is considered. One major challenge is translating lab research into field crops which can experience diverse and changeable conditions. Field trials must be conducted, as increased resistance to a particular disease could possibly have negative effects on the plants' ability to respond to different types of pathogens, abiotic stress, beneficial microorganisms or could impact crop quality [114,340-343]. Yet, importantly, knowing the detailed mechanisms of disease resistance should increase the success of new resistant crop lines in the field.

It is still technically difficult to identify and prove protein-PTM functions in vivo, but advances in the sensitivity of proteomics will improve the detection of the numerous PTMs that are dynamic or occur in low stoichiometry [42,54]. Protein phosphorylation is the bestcharacterised PTM in plants thus far, with several databases available, including the PTM viewer which identified 326,848 sites in 89,022 proteins [139,344]. One limitation is that SUMO and ubiquitin attachment site prediction can be difficult since not all SUMO sites match the consensus motif [345], and the pattern of ubiquitination sites is not conserved in different species [346]. Intriguingly, ubiquitin itself undergoes phosphorylation and other PTMs; this, combined with the architecture of ubiquitin chains, makes ubiquitination more complex [78,347]. Ubiquitin and SUMO attach to lysine residues, but other PTMs also attach to lysine, such as lysine acetylation with histone and nonhistone protein acetylation functions emerging [348,349]. Acetylation regulation is important in defence; for example, fungal and bacterial effectors disrupt host acetylation to promote virulence, such as AvrBsT which acetylates proteins such as ACIP1 to alter their defence function [170,350] (Table 1). Lysine acetylation is reversible, in contrast to N-terminal acetylation which regulates NLR protein SNC1 stability, possibly via the ubiquitin-mediated proteasomal system [117]. Thus, PTM crosstalk in plant immunity needs further exploration.

Notably, both protein-protein interactions and PTMs often depend on small regions of one or a few crucial amino acid residues [351]. In the future, CRISPR/Cas base editors or prime editors $[318,329]$ have great potential to produce precise and targeted point mutations, to change single amino acids, to alter a specific interaction of a multifunctional protein to enhance disease resistance whilst avoiding negative effects, to reduce the serious problem of crop losses from disease.

Figures 1-5 were created with Biorender.com.

Supplementary Materials: The following are available online at https:/ / www.mdpi.com/article/10 $.3390 /$ biom11081122/s1. Figure S1: ClustalW alignment of SPL protein amino acid sequences.

Author Contributions: C.G. and A.S. designed and wrote the manuscript. Both authors have read and agreed to the published version of the manuscript.

Funding: This research received no external funding.

Acknowledgments: We would like to acknowledge Rebecca Wray for helping proofread the manuscript.

Conflicts of Interest: The authors declare no conflict of interest.

\section{References}

1. Oerke, E.-C. Crop Losses to Pests. J. Agric. Sci. 2006, 144, 31-43. [CrossRef]

2. FAO. The Future of Food and Agriculture: Trends and Challenges; Food and Agriculture Organization of the United Nations, Ed.; Food and Agriculture Organization of the United Nations: Rome, Italy, 2017; ISBN 978-92-5-109551-5. 
3. IFPRI. Global Nutrition Report 2015: Actions and Accountability to Advance Nutrition and Sustainable Development; International Food Policy Research Institute: Washington, DC, USA, 2015.

4. Bass, C.; Puinean, A.M.; Zimmer, C.T.; Denholm, I.; Field, L.M.; Foster, S.P.; Gutbrod, O.; Nauen, R.; Slater, R.; Williamson, M.S. The evolution of insecticide resistance in the peach potato aphid, Myzus persicae. Insect Biochem. Mol. Biol. 2014, 51, 41-51. [CrossRef]

5. Zayan, S.A. Impact of climate change on plant diseases and IPM strategies. In Plant Disease—Current Threats and Management Trends; IntechOpen: London, UK, 2019. [CrossRef]

6. Panstruga, R.; Moscou, M.J. What is the molecular basis of nonhost resistance? Mol. Plant Microbe Interact. 2020, 33, 1253-1264. [CrossRef]

7. Das, G.; Patra, J.K.; Baek, K.-H. Insight into MAS: A molecular tool for development of stress resistant and quality of rice through gene stacking. Front. Plant Sci. 2017, 8. [CrossRef]

8. Wang, F.; Wang, C.; Liu, P.; Lei, C.; Hao, W.; Gao, Y.; Liu, Y.-G.; Zhao, K. Enhanced rice blast resistance by CRISPR/Cas9-targeted mutagenesis of the ERF transcription factor gene OsERF922. PLoS ONE 2016, 11, e0154027. [CrossRef]

9. Wang, T.; Zhang, H.; Zhu, H. CRISPR technology is revolutionizing the improvement of tomato and other fruit crops. Hortic. Res. 2019, 6, 1-13. [CrossRef] [PubMed]

10. Rampitsch, C.; Bykova, N.V. Proteomics and plant disease: Advances in combating a major threat to the global food supply. Proteomics 2012, 12, 673-690. [CrossRef] [PubMed]

11. Castro-Moretti, F.R.; Gentzel, I.N.; Mackey, D.; Alonso, A.P. Metabolomics as an emerging tool for the study of plant-pathogen interactions. Metabolites 2020, 10, 52. [CrossRef]

12. Han, G.-Z. Origin and evolution of the plant immune system. New Phytol. 2019, 222, 70-83. [CrossRef]

13. Jones, J.D.G.; Dangl, J.L. The plant immune system. Nature 2006, 444, 323-329. [CrossRef]

14. Naveed, Z.A.; Wei, X.; Chen, J.; Mubeen, H.; Ali, G.S. The PTI to ETI continuum in phytophthora-plant interactions. Front. Plant Sci. 2020, 11, 593905. [CrossRef]

15. Pritchard, L.; Birch, P.R.J. The Zigzag model of plant-microbe interactions: Is it time to move on? Mol. Plant Pathol. 2014, 15, 865-870. [CrossRef] [PubMed]

16. Stotz, H.U.; Mitrousia, G.K.; de Wit, P.J.G.M.; Fitt, B.D.L. Effector-triggered defence against apoplastic fungal pathogens. Trends Plant Sci. 2014, 19, 491-500. [CrossRef]

17. Balmer, D.; Planchamp, C.; Mauch-Mani, B. On the move: Induced resistance in monocots. J. Exp. Bot. 2013, 64, 1249-1261. [CrossRef]

18. Xin, X.-F.; Kvitko, B.; He, S.Y. Pseudomonas syringae: What it takes to be a pathogen. Nat. Rev. Microbiol. 2018, 16, 316-328. [CrossRef] [PubMed]

19. Zipfel, C. Plant pattern-recognition receptors. Trends Immunol. 2014, 35, 345-351. [CrossRef] [PubMed]

20. Felix, G.; Duran, J.D.; Volko, S.; Boller, T. Plants have a sensitive perception system for the most conserved domain of bacterial flagellin. Plant J. 1999, 18, 265-276. [CrossRef] [PubMed]

21. Gómez-Gómez, L.; Boller, T. FLS2: An LRR Receptor-like kinase involved in the perception of the bacterial elicitor flagellin in arabidopsis. Mol. Cell 2000, 5, 1003-1011. [CrossRef]

22. Kunze, G.; Zipfel, C.; Robatzek, S.; Niehaus, K.; Boller, T.; Felix, G. The N terminus of bacterial elongation factor Tu elicits innate immunity in arabidopsis plants. Plant Cell 2004, 16, 3496-3507. [CrossRef]

23. Zipfel, C.; Kunze, G.; Chinchilla, D.; Caniard, A.; Jones, J.D.G.; Boller, T.; Felix, G. Perception of the bacterial PAMP EF-Tu by the receptor EFR restricts agrobacterium-mediated transformation. Cell 2006, 125, 749-760. [CrossRef]

24. Miya, A.; Albert, P.; Shinya, T.; Desaki, Y.; Ichimura, K.; Shirasu, K.; Narusaka, Y.; Kawakami, N.; Kaku, H.; Shibuya, N. CERK1, a LysM receptor kinase, is essential for chitin elicitor signaling in arabidopsis. Proc. Natl. Acad. Sci. USA 2007, 104, 19613-19618. [CrossRef]

25. Wan, J.; Zhang, X.-C.; Neece, D.; Ramonell, K.M.; Clough, S.; Kim, S.; Stacey, M.G.; Stacey, G. A LysM receptor-like kinase plays a critical role in chitin signaling and fungal resistance in arabidopsis. Plant Cell 2008, 20, 471-481. [CrossRef] [PubMed]

26. Macho, A.P.; Zipfel, C. Plant PRRs and the activation of innate immune signaling. Mol. Cell 2014, 54, 263-272. [CrossRef]

27. Baggs, E.L.; Monroe, J.G.; Thanki, A.S.; O'Grady, R.; Schudoma, C.; Haerty, W.; Krasileva, K.V. Convergent loss of an EDS1/PAD4 Signaling pathway in several plant lineages reveals coevolved components of plant immunity and drought response. Plant Cell 2020, 32, 2158-2177. [CrossRef] [PubMed]

28. Van der Hoorn, R.A.L.; Kamoun, S. From guard to decoy: A new model for perception of plant pathogen effectors. Plant Cell 2008, 20, 2009-2017. [CrossRef]

29. Jones, J.D.G.; Vance, R.E.; Dangl, J.L. Intracellular innate immune surveillance devices in plants and animals. Science 2016, 354. [CrossRef]

30. Bernoux, M.; Ve, T.; Williams, S.; Warren, C.; Hatters, D.; Valkov, E.; Zhang, X.; Ellis, J.G.; Kobe, B.; Dodds, P.N. Structural and Functional Analysis of a Plant Resistance Protein TIR Domain Reveals Interfaces for Self-Association, signaling, and autoregulation. Cell Host Microbe 2011, 9, 200-211. [CrossRef]

31. Castel, B.; Ngou, P.-M.; Cevik, V.; Redkar, A.; Kim, D.-S.; Yang, Y.; Ding, P.; Jones, J.D.G. Diverse NLR immune receptors activate defence via the RPW8-NLR NRG1. New Phytol. 2019, 222, 966-980. [CrossRef] 
32. Wu, Z.; Li, M.; Dong, O.X.; Xia, S.; Liang, W.; Bao, Y.; Wasteneys, G.; Li, X. Differential regulation of TNL-mediated immune signaling by redundant helper CNLs. New Phytol. 2019, 222, 938-953. [CrossRef] [PubMed]

33. Wagner, S.; Stuttmann, J.; Rietz, S.; Guerois, R.; Brunstein, E.; Bautor, J.; Niefind, K.; Parker, J.E. Structural basis for signaling by exclusive EDS1 heteromeric complexes with SAG101 or PAD4 in plant innate immunity. Cell Host Microbe 2013, 14, 619-630. [CrossRef]

34. Lapin, D.; Kovacova, V.; Sun, X.; Dongus, J.A.; Bhandari, D.; von Born, P.; Bautor, J.; Guarneri, N.; Rzemieniewski, J.; Stuttmann, J.; et al. A coevolved EDS1-SAG101-NRG1 module mediates cell death signaling by TIR-domain immune receptors. Plant Cell 2019, 31, 2430-2455. [CrossRef]

35. Peng, Y.; van Wersch, R.; Zhang, Y. Convergent and divergent signaling in PAMP-triggered immunity and effector-triggered immunity. Mol. Plant Microbe Interact. 2017, 31, 403-409. [CrossRef]

36. Luna, E.; Pastor, V.; Robert, J.; Flors, V.; Mauch-Mani, B.; Ton, J. Callose Deposition: A Multifaceted Plant Defense Response. Mol. Plant Microbe Interact. 2010, 24, 183-193. [CrossRef]

37. Torres, M.A. ROS in biotic interactions. Physiol. Plant 2010, 138, 414-429. [CrossRef]

38. Torres, M.A.; Jones, J.D.G.; Dangl, J.L. Reactive oxygen species signaling in response to pathogens. Plant Physiol. 2006, 141, 373-378. [CrossRef] [PubMed]

39. Glazebrook, J. Contrasting mechanisms of defense against biotrophic and necrotrophic pathogens. Annu. Rev. Phytopathol. 2005, 43, 205-227. [CrossRef]

40. Xu, X.; Liu, X.; Yan, Y.; Wang, W.; Gebretsadik, K.; Qi, X.; Xu, Q.; Chen, X. Comparative proteomic analysis of cucumber powdery mildew resistance between a single-segment substitution line and its recurrent parent. Hortic. Res. 2019, 6, 1-13. [CrossRef] [PubMed]

41. Tahir, J.; Rashid, M.; Afzal, A.J. Post-translational modifications in effectors and plant proteins involved in host-pathogen conflicts. Plant Pathol. 2019, 68, 628-644. [CrossRef]

42. Withers, J.; Dong, X. Post-translational regulation of plant immunity. Curr. Opin. Plant Biol. 2017, 38, 124-132. [CrossRef] [PubMed]

43. Bhattacharjee, S.; Noor, J.J.; Gohain, B.; Gulabani, H.; Dnyaneshwar, I.K.; Singla, A. Post-translational modifications in regulation of pathogen surveillance and signaling in plants: The inside- (and perturbations from) outside story. IUBMB Life 2015, 67, 524-532. [CrossRef]

44. Bigeard, J.; Hirt, H. Nuclear signaling of plant MAPKs. Front. Plant Sci. 2018, 9. [CrossRef]

45. Lin, W.; Li, B.; Lu, D.; Chen, S.; Zhu, N.; He, P.; Shan, L. Tyrosine phosphorylation of protein kinase complex BAK1/BIK1 mediates arabidopsis innate immunity. Proc. Natl. Acad. Sci. USA 2014, 111, 3632-3637. [CrossRef]

46. Wang, Y.; Li, Z.; Liu, D.; Xu, J.; Wei, X.; Yan, L.; Yang, C.; Lou, Z.; Shui, W. Assessment of BAK1 activity in different plant receptor-like kinase complexes by quantitative profiling of phosphorylation patterns. J. Proteom. 2014, 108, 484-493. [CrossRef]

47. Laluk, K.; Luo, H.; Chai, M.; Dhawan, R.; Lai, Z.; Mengiste, T. Biochemical and genetic requirements for function of the immune response regulator BOTRYTIS-INDUCED KINASE1 in Plant Growth, Ethylene Signaling, and PAMP-triggered immunity in Arabidopsis. Plant Cell 2011, 23, 2831-2849. [CrossRef] [PubMed]

48. Orosa, B.; Yates, G.; Verma, V.; Srivastava, A.K.; Srivastava, M.; Campanaro, A.; Vega, D.D.; Fernandes, A.; Zhang, C.; Lee, J.; et al. SUMO conjugation to the pattern recognition receptor FLS2 triggers intracellular signalling in plant innate immunity. Nat. Commun. 2018, 9, 5185. [CrossRef]

49. Kadota, Y.; Sklenar, J.; Derbyshire, P.; Stransfeld, L.; Asai, S.; Ntoukakis, V.; Jones, J.D.; Shirasu, K.; Menke, F.; Jones, A.; et al. Direct regulation of the NADPH oxidase RBOHD by the PRR-associated kinase BIK1 during plant immunity. Mol. Cell 2014, 54, 43-55. [CrossRef] [PubMed]

50. Li, L.; Li, M.; Yu, L.; Zhou, Z.; Liang, X.; Liu, Z.; Cai, G.; Gao, L.; Zhang, X.; Wang, Y.; et al. The FLS2-associated kinase BIK1 directly phosphorylates the NADPH oxidase RbohD to control plant immunity. Cell Host Microbe 2014, 15, 329-338. [CrossRef] [PubMed]

51. Kim, T.-W.; Wang, Z.-Y. Brassinosteroid signal transduction from receptor kinases to transcription factors. Annu. Rev. Plant Biol. 2010, 61, 681-704. [CrossRef]

52. Yan, L.; Ma, Y.; Liu, D.; Wei, X.; Sun, Y.; Chen, X.; Zhao, H.; Zhou, J.; Wang, Z.; Shui, W.; et al. Structural basis for the impact of phosphorylation on the activation of plant receptor-like kinase BAK1. Cell Res. 2012, 22, 1304-1308. [CrossRef] [PubMed]

53. Wang, X.; Kota, U.; He, K.; Blackburn, K.; Li, J.; Goshe, M.B.; Huber, S.C.; Clouse, S.D. Sequential transphosphorylation of the BRI1/BAK1 receptor kinase complex impacts early events in brassinosteroid signaling. Dev. Cell 2008, 15, 220-235. [CrossRef]

54. Schwessinger, B.; Roux, M.; Kadota, Y.; Ntoukakis, V.; Sklenar, J.; Jones, A.; Zipfel, C. Phosphorylation-dependent differential regulation of plant growth, cell death, and innate immunity by the regulatory receptor-like kinase BAK1. PLoS Genet. 2011, 7, e1002046. [CrossRef] [PubMed]

55. Chinchilla, D.; Zipfel, C.; Robatzek, S.; Kemmerling, B.; Nürnberger, T.; Jones, J.D.G.; Felix, G.; Boller, T. A Flagellin-induced complex of the receptor FLS2 and BAK1 initiates plant defence. Nature 2007, 448, 497-500. [CrossRef]

56. Perraki, A.; DeFalco, T.A.; Derbyshire, P.; Avila, J.; Séré, D.; Sklenar, J.; Qi, X.; Stransfeld, L.; Schwessinger, B.; Kadota, Y.; et al. Phosphocode-dependent functional dichotomy of a common co-receptor in plant signalling. Nature 2018, 561, 248-252. [CrossRef]

57. Jagodzik, P.; Tajdel-Zielinska, M.; Ciesla, A.; Marczak, M.; Ludwikow, A. Mitogen-activated protein kinase cascades in plant hormone signaling. Front. Plant Sci. 2018, 9. [CrossRef] 
58. Bi, G.; Zhou, Z.; Wang, W.; Li, L.; Rao, S.; Wu, Y.; Zhang, X.; Menke, F.L.H.; Chen, S.; Zhou, J.-M. Receptor-like cytoplasmic kinases directly link diverse pattern recognition receptors to the activation of mitogen-activated protein kinase cascades in Arabidopsis. Plant Cell 2018, 30, 1543-1561. [CrossRef] [PubMed]

59. Berriri, S.; Garcia, A.V.; dit Frey, N.F.; Rozhon, W.; Pateyron, S.; Leonhardt, N.; Montillet, J.-L.; Leung, J.; Hirt, H.; Colcombet, J. Constitutively Active Mitogen-Activated Protein Kinase Versions Reveal Functions of Arabidopsis MPK4 in pathogen defense signaling. Plant Cell 2012, 24, 4281-4293. [CrossRef]

60. Genot, B.; Lang, J.; Berriri, S.; Garmier, M.; Gilard, F.; Pateyron, S.; Haustraete, K.; Van Der Straeten, D.; Hirt, H.; Colcombet, J. Constitutively Active Arabidopsis MAP Kinase 3 Triggers Defense Responses Involving Salicylic Acid and SUMM2 resistance protein1. Plant Physiol. 2017, 174, 1238-1249. [CrossRef] [PubMed]

61. Kong, Q.; Qu, N.; Gao, M.; Zhang, Z.; Ding, X.; Yang, F.; Li, Y.; Dong, O.X.; Chen, S.; Li, X.; et al. The MEKK1-MKK1/MKK2-MPK4 kinase cascade negatively regulates immunity mediated by a mitogen-activated protein kinase kinase kinase in Arabidopsis. Plant Cell 2012, 24, 2225-2236. [CrossRef]

62. Petersen, M.; Brodersen, P.; Naested, H.; Andreasson, E.; Lindhart, U.; Johansen, B.; Nielsen, H.B.; Lacy, M.; Austin, M.J.; Parker, J.E.; et al. Arabidopsis MAP kinase 4 negatively regulates systemic acquired resistance. Cell 2000, 103, 1111-1120. [CrossRef]

63. Mao, G.; Meng, X.; Liu, Y.; Zheng, Z.; Chen, Z.; Zhang, S. Phosphorylation of a WRKY transcription factor by two pathogenresponsive MAPKs drives phytoalexin biosynthesis in Arabidopsis. Plant Cell 2011, 23, 1639-1653. [CrossRef] [PubMed]

64. Zhou, N.; Tootle, T.L.; Glazebrook, J. Arabidopsis PAD3, a gene required for camalexin biosynthesis, encodes a putative cytochrome P450 monooxygenase. Plant Cell 1999, 11, 2419-2428. [CrossRef]

65. Su, J.; Yang, L.; Zhu, Q.; Wu, H.; He, Y.; Liu, Y.; Xu, J.; Jiang, D.; Zhang, S. Active photosynthetic inhibition mediated by MPK3/MPK6 is critical to effector-triggered immunity. PLoS Biol. 2018, 16, e2004122. [CrossRef]

66. Zhang, Z.; Wu, Y.; Gao, M.; Zhang, J.; Kong, Q.; Liu, Y.; Ba, H.; Zhou, J.; Zhang, Y. Disruption of PAMP-induced MAP kinase cascade by a Pseudomonas syringae effector activates plant immunity mediated by the NB-LRR protein SUMM2. Cell Host Microbe 2012, 11, 253-263. [CrossRef] [PubMed]

67. Zhang, Z.; Liu, Y.; Huang, H.; Gao, M.; Wu, D.; Kong, Q.; Zhang, Y. The NLR protein SUMM2 senses the disruption of an immune signaling MAP kinase cascade via CRCK3. EMBO Rep. 2017, 18, 292-302. [CrossRef]

68. Wang, W.; Feng, B.; Zhou, J.-M.; Tang, D. Plant immune signaling: Advancing on two frontiers. J. Integr. Plant Biol. 2020, 62, 2-24. [CrossRef]

69. Segonzac, C.; Macho, A.P.; Sanmartín, M.; Ntoukakis, V.; Sánchez-Serrano, J.J.; Zipfel, C. Negative control of BAK1 by protein phosphatase 2A during plant innate immunity. EMBO J. 2014, 33, 2069-2079. [CrossRef]

70. Couto, D.; Niebergall, R.; Liang, X.; Bücherl, C.A.; Sklenar, J.; Macho, A.P.; Ntoukakis, V.; Derbyshire, P.; Altenbach, D.; Maclean, D.; et al. The Arabidopsis protein phosphatase PP2C38 negatively regulates the central immune kinase BIK1. PLOS Pathog. 2016, 12, e1005811. [CrossRef]

71. Liu, J.; Liu, B.; Chen, S.; Gong, B.-Q.; Chen, L.; Zhou, Q.; Xiong, F.; Wang, M.; Feng, D.; Li, J.-F.; et al. A Tyrosine phosphorylation cycle regulates fungal activation of a plant receptor Ser/Thr kinase. Cell Host Microbe 2018, 23, 241-253.e6. [CrossRef] [PubMed]

72. Schweighofer, A.; Kazanaviciute, V.; Scheikl, E.; Teige, M.; Doczi, R.; Hirt, H.; Schwanninger, M.; Kant, M.; Schuurink, R.; Mauch, F.; et al. The PP2C-type phosphatase AP2C1, which negatively regulates MPK4 and MPK6, modulates innate immunity, jasmonic acid, and ethylene levels in Arabidopsis. Plant Cell 2007, 19, 2213-2224. [CrossRef] [PubMed]

73. Shubchynskyy, V.; Boniecka, J.; Schweighofer, A.; Simulis, J.; Kvederaviciute, K.; Stumpe, M.; Mauch, F.; Balazadeh, S.; MuellerRoeber, B.; Boutrot, F.; et al. Protein phosphatase AP2C1 negatively regulates basal resistance and defense responses to Pseudomonas syringae. J. Exp. Bot. 2017, 68, 1169-1183. [CrossRef] [PubMed]

74. Anderson, J.C.; Bartels, S.; Besteiro, M.A.G.; Shahollari, B.; Ulm, R.; Peck, S.C. Arabidopsis MAP kinase phosphatase 1 (AtMKP1) negatively regulates MPK6-mediated PAMP responses and resistance against bacteria. Plant J. 2011, 67, 258-268. [CrossRef] [PubMed]

75. Bartels, S.; Anderson, J.C.; González Besteiro, M.A.; Carreri, A.; Hirt, H.; Buchala, A.; Métraux, J.-P.; Peck, S.C.; Ulm, R. MAP kinase phosphatase 1 and protein tyrosine phosphatase1 are repressors of salicylic acid synthesis and SNC1-mediated responses in Arabidopsis. Plant Cell 2009, 21, 2884-2897. [CrossRef]

76. Park, H.C.; Song, E.H.; Nguyen, X.C.; Lee, K.; Kim, K.E.; Kim, H.S.; Lee, S.M.; Kim, S.H.; Bae, D.W.; Yun, D.-J.; et al. Arabidopsis MAP kinase phosphatase 1 is phosphorylated and activated by its substrate AtMPK6. Plant Cell Rep. 2011, 30, $1523-1531$. [CrossRef] [PubMed]

77. Callis, J. The ubiquitination machinery of the ubiquitin system. Arabidopsis Book 2014, 12. [CrossRef] [PubMed]

78. Komander, D.; Rape, M. The ubiquitin code. Annu. Rev. Biochem. 2012, 81, 203-229. [CrossRef]

79. Vierstra, R.D. The ubiquitin-26S proteasome system at the nexus of plant biology. Nat. Rev. Mol. Cell. Biol. 2009, 10, 385-397. [CrossRef]

80. Zhou, B.; Zeng, L. Conventional and unconventional ubiquitination in plant immunity. Mol. Plant Pathol. 2017, 18, 1313-1330. [CrossRef] [PubMed]

81. Kachewar, N.R.; Gupta, V.; Ranjan, A.; Patel, H.K.; Sonti, R.V. Overexpression of OsPUB41, a rice E3 ubiquitin ligase induced by cell wall degrading enzymes, enhances immune responses in rice and Arabidopsis. BMC Plant Biol. 2019, 19, 530. [CrossRef]

82. Becker, F.; Buschfeld, E.; Schell, J.; Bachmair, A. Altered response to viral infection by tobacco plants perturbed in ubiquitin system. Plant J. 1993, 3, 875-881. [CrossRef] 
83. Goritschnig, S.; Zhang, Y.; Li, X. The ubiquitin pathway is required for innate immunity in Arabidopsis. Plant J. 2007, 49, 540-551. [CrossRef] [PubMed]

84. Saeki, Y. Ubiquitin recognition by the proteasome. J. Biochem. 2017, 161, 113-124. [CrossRef]

85. Duplan, V.; Rivas, S. E3 Ubiquitin-ligases and their target proteins during the regulation of plant innate immunity. Front. Plant Sci. 2014, 5. [CrossRef]

86. Lu, D.; Lin, W.; Gao, X.; Wu, S.; Cheng, C.; Avila, J.; Heese, A.; Devarenne, T.P.; He, P.; Shan, L. Direct ubiquitination of pattern recognition receptor FLS2 attenuates plant innate immunity. Science 2011, 332, 1439-1442. [CrossRef] [PubMed]

87. Zhou, J.; Lu, D.; Xu, G.; Finlayson, S.A.; He, P.; Shan, L. The dominant negative ARM domain uncovers multiple functions of PUB13 in Arabidopsis immunity, flowering, and senescence. J. Exp. Bot. 2015, 66, 3353-3366. [CrossRef] [PubMed]

88. Liao, D.; Cao, Y.; Sun, X.; Espinoza, C.; Nguyen, C.T.; Liang, Y.; Stacey, G. Arabidopsis E3 ubiquitin ligase plant U-BOX13 (PUB13) regulates chitin receptor lysin motif receptor kinase5 (LYK5) protein abundance. New Phytol. 2017, 214, 1646-1656. [CrossRef] [PubMed]

89. Wang, J.; Grubb, L.E.; Wang, J.; Liang, X.; Li, L.; Gao, C.; Ma, M.; Feng, F.; Li, M.; Li, L.; et al. A regulatory module controlling homeostasis of a plant immune kinase. Mol. Cell 2018, 69, 493-504.e6. [CrossRef]

90. Desaki, Y.; Takahashi, S.; Sato, K.; Maeda, K.; Matsui, S.; Yoshimi, I.; Miura, T.; Jumonji, J.-I.; Takeda, J.; Yashima, K.; et al. PUB4, a CERK1-interacting ubiquitin ligase, positively regulates MAMP-triggered immunity in Arabidopsis. Plant Cell Physiol. 2019, 60, 2573-2583. [CrossRef]

91. Thines, B.; Katsir, L.; Melotto, M.; Niu, Y.; Mandaokar, A.; Liu, G.; Nomura, K.; He, S.Y.; Howe, G.A.; Browse, J. JAZ repressor proteins are targets of the SCF COI1 complex during jasmonate signalling. Nature 2007, 448, 661-665. [CrossRef]

92. Xie, D.-X.; Feys, B.F.; James, S.; Nieto-Rostro, M.; Turner, J.G. COI1: An Arabidopsis gene required for jasmonate-regulated defense and fertility. Science 1998, 280, 1091-1094. [CrossRef]

93. Xu, L.; Liu, F.; Lechner, E.; Genschik, P.; Crosby, W.L.; Ma, H.; Peng, W.; Huang, D.; Xie, D. The SCFCOI1 ubiquitin-ligase complexes are required for jasmonate response in Arabidopsis. Plant Cell 2002, 14, 1919-1935. [CrossRef]

94. Huang, S.; Chen, X.; Zhong, X.; Li, M.; Ao, K.; Huang, J.; Li, X. Plant TRAF proteins regulate NLR immune receptor turnover. Cell Host Microbe 2016, 19, 204-215. [CrossRef] [PubMed]

95. Mazzucotelli, E.; Belloni, S.; Marone, D.; De Leonardis, A.; Guerra, D.; Di Fonzo, N.; Cattivelli, L.; Mastrangelo, A. The E3 ubiquitin ligase gene family in plants: Regulation by degradation. Curr. Genom. 2006, 7, 509-522. [CrossRef] [PubMed]

96. Vierstra, R.D. The expanding universe of ubiquitin and ubiquitin-like modifiers. Plant Physiol. 2012, 160, 2-14. [CrossRef]

97. Wu, Z.; Tong, M.; Tian, L.; Zhu, C.; Liu, X.; Zhang, Y.; Li, X. Plant E3 ligases SNIPER1 and SNIPER2 broadly regulate the homeostasis of sensor NLR immune receptors. EMBO J. 2020, e104915. [CrossRef]

98. Nijman, S.M.B.; Luna-Vargas, M.P.A.; Velds, A.; Brummelkamp, T.R.; Dirac, A.M.G.; Sixma, T.K.; Bernards, R. A genomic and functional inventory of deubiquitinating enzymes. Cell 2005, 123, 773-786. [CrossRef]

99. Ewan, R.; Pangestuti, R.; Thornber, S.; Craig, A.; Carr, C.; O’Donnell, L.; Zhang, C.; Sadanandom, A. Deubiquitinating enzymes AtUBP12 and AtUBP13 and their tobacco homologue NtUBP12 are negative regulators of plant immunity. New Phytol. 2011, 191, 92-106. [CrossRef]

100. Jeong, J.S.; Jung, C.; Seo, J.S.; Kim, J.-K.; Chua, N.-H. The deubiquitinating enzymes UBP12 and UBP13 positively regulate MYC2 levels in jasmonate responses. Plant Cell 2017, 29, 1406-1424. [CrossRef]

101. Bailey, M.; Srivastava, A.; Conti, L.; Nelis, S.; Zhang, C.; Florance, H.; Love, A.; Milner, J.; Napier, R.; Grant, M.; et al. Stability of small ubiquitin-like modifier (SUMO) proteases overly tolerant to salt1 and -2 modulates salicylic acid signalling and SUMO1/2 conjugation in Arabidopsis thaliana. J. Exp. Bot. 2016, 67, 353-363. [CrossRef] [PubMed]

102. Colignon, B.; Delaive, E.; Dieu, M.; Demazy, C.; Muhovski, Y.; Wallon, C.; Raes, M.; Mauro, S. Proteomics analysis of the endogenous, constitutive, leaf SUMOylome. J. Proteom. 2017, 150, 268-280. [CrossRef]

103. Ingole, K.D.; Dahale, S.K.; Bhattacharjee, S. Proteomic analysis of SUMO1-SUMOylome changes during defense elicitation in Arabidopsis. J. Proteom. 2021, 232, 104054. [CrossRef]

104. Miller, M.J.; Barrett-Wilt, G.A.; Hua, Z.; Vierstra, R.D. Proteomic analyses identify a diverse array of nuclear processes affected by small ubiquitin-like modifier conjugation in Arabidopsis. Proc. Natl. Acad. Sci. USA 2010, 107, 16512-16517. [CrossRef] [PubMed]

105. Kim, S.H.; Gao, F.; Bhattacharjee, S.; Adiasor, J.A.; Nam, J.C.; Gassmann, W. The Arabidopsis Resistance-Like Gene SNC1 is activated by mutations in SRFR1 and contributes to resistance to the bacterial effector AvrRps4. PLoS Pathog. 2010, 6, e1001172. [CrossRef]

106. Bhattacharjee, S.; Halane, M.K.; Kim, S.H.; Gassmann, W. Pathogen effectors target Arabidopsis EDS1 and alter its interactions with immune regulators. Science 2011, 334, 1405-1408. [CrossRef] [PubMed]

107. Hammoudi, V.; Vlachakis, G.; Schranz, M.E.; van den Burg, H.A. Whole-genome duplications followed by tandem duplications drive diversification of the protein modifier SUMO in angiosperms. New Phytol. 2016, 211, 172-185. [CrossRef] [PubMed]

108. Kurepa, J.; Walker, J.M.; Smalle, J.; Gosink, M.M.; Davis, S.J.; Durham, T.L.; Sung, D.-Y.; Vierstra, R.D. The small ubiquitin-like modifier (SUMO) protein modification system in Arabidopsis accumulation of sumo1 and -2 conjugates is increased by stress. J. Biol. Chem. 2003, 278, 6862-6872. [CrossRef]

109. Van denBurg, H.A.; Kini, R.K.; Schuurink, R.C.; Takken, F.L.W. Arabidopsis small ubiquitin-like modifier paralogs have distinct functions in development and defense. Plant Cell 2010, 22, 1998-2016. [CrossRef] 
110. Merrill, J.C.; Melhuish, T.A.; Kagey, M.H.; Yang, S.-H.; Sharrocks, A.D.; Wotton, D. A role for non-covalent SUMO interaction motifs in Pc2/CBX4 E3 activity. PLoS ONE 2010, 5, e8794. [CrossRef] [PubMed]

111. Villajuana-Bonequi, M.; Elrouby, N.; Nordström, K.; Griebel, T.; Bachmair, A.; Coupland, G. Elevated salicylic acid levels conferred by increased expression of isochorismate synthase 1 Contribute to Hyperaccumulation of SUMO1 conjugates in the Arabidopsis mutant early in short days 4. Plant J. 2014, 79, 206-219. [CrossRef]

112. Lee, J.; Nam, J.; Park, H.C.; Na, G.; Miura, K.; Jin, J.B.; Yoo, C.Y.; Baek, D.; Kim, D.H.; Jeong, J.C.; et al. Salicylic acid-mediated innate immunity in arabidopsis is regulated by SIZ1 SUMO E3 ligase. Plant J. 2007, 49, 79-90. [CrossRef] [PubMed]

113. Gou, M.; Huang, Q.; Qian, W.; Zhang, Z.; Jia, Z.; Hua, J. Sumoylation E3 Ligase SIZ1 modulates plant immunity partly through the immune receptor gene SNC1 in Arabidopsis. Mol. Plant Microbe Interact. 2017, 30, 334-342. [CrossRef]

114. Hammoudi, V.; Fokkens, L.; Beerens, B.; Vlachakis, G.; Chatterjee, S.; Arroyo-Mateos, M.; Wackers, P.F.K.; Jonker, M.J.; van den Burg, H.A. The Arabidopsis SUMO E3 Ligase SIZ1 mediates the temperature dependent trade-off between plant immunity and growth. PLoS Genet. 2018, 14, e1007157. [CrossRef] [PubMed]

115. Niu, D.; Lin, X.-L.; Kong, X.; Qu, G.-P.; Cai, B.; Lee, J.; Jin, J.B. SIZ1-Mediated SUMOylation of TPR1 suppresses plant immunity in Arabidopsis. Mol. Plant 2019, 12, 215-228. [CrossRef] [PubMed]

116. Gou, M.; Shi, Z.; Zhu, Y.; Bao, Z.; Wang, G.; Hua, J. The F-Box protein CPR1/CPR30 negatively regulates R protein SNC1 accumulation. Plant J. 2012, 69, 411-420. [CrossRef]

117. Zhang, Y.; Zeng, L. Crosstalk between ubiquitination and other post-translational protein modifications in plant immunity. Plant Commun. 2020, 100041. [CrossRef] [PubMed]

118. Srivastava, A.K.; Orosa, B.; Singh, P.; Cummins, I.; Walsh, C.; Zhang, C.; Grant, M.; Roberts, M.R.; Anand, G.S.; Fitches, E.; et al. SUMO Suppresses the activity of the jasmonic acid receptor coronatine insensitive1. Plant Cell 2018, 30, 2099-2115. [CrossRef]

119. Cao, Y.; Aceti, D.J.; Sabat, G.; Song, J.; Makino, S.-I.; Fox, B.G.; Bent, A.F. Mutations in FLS2 Ser-938 dissect signaling activation in FLS2-mediated Arabidopsis immunity. PLoS Pathog. 2013, 9, e1003313. [CrossRef]

120. Chinchilla, D.; Bauer, Z.; Regenass, M.; Boller, T.; Felix, G. The Arabidopsis receptor kinase FLS2 binds Flg22 and determines the specificity of flagellin perception. Plant Cell 2006, 18, 465-476. [CrossRef]

121. Lu, D.; Wu, S.; Gao, X.; Zhang, Y.; Shan, L.; He, P. A receptor-like cytoplasmic kinase, BIK1, associates with a flagellin receptor complex to initiate plant innate immunity. Proc. Natl. Acad. Sci. USA 2010, 107, 496-501. [CrossRef]

122. Sun, Y.; Li, L.; Macho, A.P.; Han, Z.; Hu, Z.; Zipfel, C.; Zhou, J.-M.; Chai, J. Structural basis for Flg22-induced activation of the Arabidopsis FLS2-BAK1 immune complex. Science 2013, 342, 624-628. [CrossRef] [PubMed]

123. Ma, X.; Claus, L.A.N.; Leslie, M.E.; Tao, K.; Wu, Z.; Liu, J.; Yu, X.; Li, B.; Zhou, J.; Savatin, D.V.; et al. Ligand-induced monoubiquitination of BIK1 regulates plant immunity. Nature 2020, 581, 199-203. [CrossRef]

124. Monaghan, J.; Matschi, S.; Romeis, T.; Zipfel, C. The calcium-dependent protein kinase CPK28 negatively regulates the BIK1mediated PAMP-induced calcium burst. Plant Signal. Behav. 2015, 10. [CrossRef]

125. Yin, J.; Yi, H.; Chen, X.; Wang, J. Post-translational modifications of proteins have versatile roles in regulating plant immune responses. Int. J. Mol. Sci. 2019, 20, 2807. [CrossRef]

126. Withers, J.; Dong, X. Posttranslational Modifications of NPR1: A single protein playing multiple roles in plant immunity and physiology. PLoS Pathog. 2016, 12, e1005707. [CrossRef]

127. Després, C.; DeLong, C.; Glaze, S.; Liu, E.; Fobert, P.R. The Arabidopsis NPR1/NIM1 protein enhances the DNA binding activity of a subgroup of the TGA family of BZIP transcription factors. Plant Cell 2000, 12, 279-290. [CrossRef]

128. Saleh, A.; Withers, J.; Mohan, R.; Marqués, J.; Gu, Y.; Yan, S.; Zavaliev, R.; Nomoto, M.; Tada, Y.; Dong, X. Posttranslational modifications of the master transcriptional regulator NPR1 enable dynamic but tight control of plant immune responses. Cell Host Microbe 2015, 18, 169-182. [CrossRef]

129. Spoel, S.H.; Mou, Z.; Tada, Y.; Spivey, N.W.; Genschik, P.; Dong, X. Proteasome-mediated turnover of the transcription co-activator NPR1 plays dual roles in regulating plant immunity. Cell 2009, 137, 860-872. [CrossRef]

130. Fu, Z.Q.; Yan, S.; Saleh, A.; Wang, W.; Ruble, J.; Oka, N.; Mohan, R.; Spoel, S.H.; Tada, Y.; Zheng, N.; et al. NPR3 and NPR4 are receptors for the immune signal salicylic acid in plants. Nature 2012, 486, 228-232. [CrossRef] [PubMed]

131. Van Loon, L.C.; Rep, M.; Pieterse, C.M.J. Significance of inducible defense-related proteins in infected plants. Annu. Rev. Phytopathol. 2006, 44, 135-162. [CrossRef]

132. He, Z.; Huang, T.; Ao, K.; Yan, X.; Huang, Y. Sumoylation, phosphorylation, and acetylation fine-tune the turnover of plant immunity components mediated by ubiquitination. Front. Plant Sci. 2017, 8. [CrossRef] [PubMed]

133. Backer, R.; Naidoo, S.; van den Berg, N. The nonexpressor of pathogenesis-related genes 1 (NPR1) and related family: Mechanistic insights in plant disease resistance. Front. Plant Sci. 2019, 10. [CrossRef] [PubMed]

134. Lim, G.-H.; Hoey, T.; Zhu, S.; Clavel, M.; Yu, K.; Navarre, D.; Kachroo, A.; Deragon, J.-M.; Kachroo, P. COP1, a Negative regulator of photomorphogenesis, positively regulates plant disease resistance via double-stranded RNA binding proteins. PLoS Pathog. 2018, 14, e1006894. [CrossRef]

135. Lin, X.-L.; Niu, D.; Hu, Z.-L.; Kim, D.H.; Jin, Y.H.; Cai, B.; Liu, P.; Miura, K.; Yun, D.-J.; Kim, W.-Y.; et al. An Arabidopsis SUMO E3 ligase, SIZ1, negatively regulates photomorphogenesis by promoting COP1 activity. PLoS Genet. 2016, 12, e1006016. [CrossRef]

136. Kim, J.Y.; Jang, I.-C.; Seo, H.S. COP1 controls abiotic stress responses by modulating AtSIZ1 function through its E3 ubiquitin ligase activity. Front. Plant Sci. 2016, 7. [CrossRef] 
137. Van den Burg, H.A.; Takken, F.L. SUMO-, MAPK- and resistance protein-signaling converge at transcription complexes that regulate plant innate immunity. Plant Signal. Behav. 2010, 5, 1597-1601. [CrossRef] [PubMed]

138. Verma, V.; Srivastava, A.K.; Gough, C.; Campanaro, A.; Srivastava, M.; Morrell, R.; Joyce, J.; Bailey, M.; Krysan, P.J.; Sadanandom, A. SUMO enables substrate selectivity by mitogen-activated protein kinases to regulate immunity in plants. Proc. Nat. Acad. Sci. USA 2021, 118, e2021351118. [CrossRef]

139. Willems, P.; Horne, A.; Parys, T.V.; Goormachtig, S.; Smet, I.D.; Botzki, A.; Breusegem, F.V.; Gevaert, K. The plant PTM viewer, a central resource for exploring plant protein modifications. Plant J. 2019, 99, 752-762. [CrossRef] [PubMed]

140. Hotson, A.; Chosed, R.; Shu, H.; Orth, K.; Mudgett, M.B. Xanthomonas type III effector XopD targets SUMO-conjugated proteins in planta. Mol. Microbiol. 2003, 50, 377-389. [CrossRef] [PubMed]

141. Park, C.H.; Shirsekar, G.; Bellizzi, M.; Chen, S.; Songkumarn, P.; Xie, X.; Shi, X.; Ning, Y.; Zhou, B.; Suttiviriya, P.; et al. The E3 ligase APIP10 connects the effector AvrPiz-t to the NLR receptor Piz-t in rice. PLoS Pathog. 2016, 12, e1005529. [CrossRef]

142. Yin, Z.; Chen, J.; Zeng, L.; Goh, M.; Leung, H.; Khush, G.S.; Wang, G.L. Characterizing rice lesion mimic mutants and identifying a mutant with broad-spectrum resistance to rice blast and bacterial blight. Mol. Plant Microbe Interact. 2000, 13, 869-876. [CrossRef]

143. Zeng, L.-R.; Qu, S.; Bordeos, A.; Yang, C.; Baraoidan, M.; Yan, H.; Xie, Q.; Nahm, B.H.; Leung, H.; Wang, G.-L. Spotted leaf11, a negative regulator of plant cell death and defense, encodes a U-Box/armadillo repeat protein endowed with E3 ubiquitin ligase activity. Plant Cell 2004, 16, 2795-2808. [CrossRef] [PubMed]

144. Zhou, B.; Zeng, L. The tomato U-Box type E3 ligase PUB13 acts with group III ubiquitin E2 enzymes to modulate FLS2-mediated immune signaling. Front. Plant Sci. 2018, 9. [CrossRef]

145. Kumar, S.P.; Dalal, V.; Singh, N.K.; Sharma, T.R. Comparative Analysis of the $100 \mathrm{~Kb}$ region containing the Pi-Kh locus between Indica and Japonica rice lines. Genom. Proteom. Bioinform. 2007, 5, 35-44. [CrossRef]

146. Vasudevan, K.; Gruissem, W.; Bhullar, N.K. Identification of novel alleles of the rice blast resistance gene Pi54. Sci. Rep. 2015, 5. [CrossRef] [PubMed]

147. Chen, X.; Chern, M.; Canlas, P.E.; Jiang, C.; Ruan, D.; Cao, P.; Ronald, P.C. A conserved threonine residue in the juxtamembrane domain of the XA21 pattern recognition receptor is critical for kinase autophosphorylation and XA21-mediated immunity. J. Biol. Chem. 2010, 285, 10454-10463. [CrossRef]

148. Wang, Y.-S.; Pi, L.-Y.; Chen, X.; Chakrabarty, P.K.; Jiang, J.; Leon, A.L.D.; Liu, G.-Z.; Li, L.; Benny, U.; Oard, J.; et al. Rice XA21 binding protein 3 is a ubiquitin ligase required for full Xa21-mediated disease resistance. Plant Cell 2006, 18, 3635-3646. [CrossRef] [PubMed]

149. Luu, D.D.; Joe, A.; Chen, Y.; Parys, K.; Bahar, O.; Pruitt, R.; Chan, L.J.G.; Petzold, C.J.; Long, K.; Adamchak, C.; et al. Biosynthesis and secretion of the microbial sulfated peptide RaxX and binding to the rice XA21 immune receptor. Proc. Natl. Acad. Sci. USA 2019, 116, 8525-8534. [CrossRef]

150. Park, C.-J.; Han, S.-W.; Chen, X.; Ronald, P.C. Elucidation of XA21-mediated innate immunity. Cell Microbiol. 2010, 12, 1017-1025. [CrossRef]

151. Huang, X.; Liu, X.; Chen, X.; Snyder, A.; Song, W.-Y. Members of the XB3 family from diverse plant species induce programmed cell death in Nicotiana benthamiana. PLoS ONE 2013, 8, e63868. [CrossRef]

152. Gimenez-Ibanez, S.; Hann, D.R.; Ntoukakis, V.; Petutschnig, E.; Lipka, V.; Rathjen, J.P. AvrPtoB targets the LysM receptor kinase CERK1 to promote bacterial virulence on plants. Curr. Biol. 2009, 19, 423-429. [CrossRef] [PubMed]

153. Göhre, V.; Spallek, T.; Häweker, H.; Mersmann, S.; Mentzel, T.; Boller, T.; de Torres, M.; Mansfield, J.W.; Robatzek, S. Plant pattern-recognition receptor FLS2 is directed for degradation by the bacterial ubiquitin ligase AvrPtoB. Curr. Biol. 2008, 18, 1824-1832. [CrossRef]

154. Rosebrock, T.R.; Zeng, L.; Brady, J.J.; Abramovitch, R.B.; Xiao, F.; Martin, G.B. A Bacterial E3 ubiquitin ligase targets a host protein kinase to disrupt plant immunity. Nature 2007, 448, 370-374. [CrossRef]

155. Mathieu, J.; Schwizer, S.; Martin, G.B. Pto Kinase Binds Two Domains of AvrPtoB and Its Proximity to the Effector E3 ligase determines if it evades degradation and activates plant immunity. PLoS Pathog. 2014, 10, e1004227. [CrossRef]

156. Luo, Y.; Caldwell, K.S.; Wroblewski, T.; Wright, M.E.; Michelmore, R.W. Proteolysis of a negative regulator of innate immunity is dependent on resistance genes in tomato and Nicotiana benthamiana and induced by multiple bacterial effectors. Plant Cell 2009, 21, 2458-2472. [CrossRef] [PubMed]

157. Xiang, T.; Zong, N.; Zou, Y.; Wu, Y.; Zhang, J.; Xing, W.; Li, Y.; Tang, X.; Zhu, L.; Chai, J.; et al. Pseudomonas syringae effector AvrPto blocks innate immunity by targeting receptor kinases. Curr. Biol. 2008, 18, 74-80. [CrossRef]

158. Mackey, D.; Holt, B.F.; Wiig, A.; Dangl, J.L. RIN4 interacts with Pseudomonas syringae type III effector molecules and is required for RPM1-mediated resistance in Arabidopsis. Cell 2002, 108, 743-754. [CrossRef]

159. Zhou, J.; Wu, S.; Chen, X.; Liu, C.; Sheen, J.; Shan, L.; He, P. Pseudomonas syringae effector HopF2 suppresses Arabidopsis immunity by targeting BAK1. Plant J. 2014, 77, 235-245. [CrossRef] [PubMed]

160. Wilton, M.; Subramaniam, R.; Elmore, J.; Felsensteiner, C.; Coaker, G.; Desveaux, D. The type III effector HopF $2_{P t o}$ targets Arabidopsis RIN4 protein to promote Pseudomonas syringae virulence. Proc. Natl. Acad. Sci. USA 2010, 107, 2349-2354. [CrossRef] [PubMed]

161. Singh, D.K.; Calviño, M.; Brauer, E.K.; Fernandez-Pozo, N.; Strickler, S.; Yalamanchili, R.; Suzuki, H.; Aoki, K.; Shibata, D.; Stratmann, J.W.; et al. The Tomato Kinome and the Tomato Kinase Library ORFeome: Novel resources for the study of kinases and signal transduction in tomato and solanaceae species. Mol. Plant Microbe Interact. 2013, 27, 7-17. [CrossRef] [PubMed] 
162. Wang, Y.; Li, J.; Hou, S.; Wang, X.; Li, Y.; Ren, D.; Chen, S.; Tang, X.; Zhou, J.-M. A Pseudomonas syringae ADP-ribosyltransferase inhibits arabidopsis mitogen-activated protein kinase kinases. Plant Cell 2010, 22, 2033-2044. [CrossRef]

163. Zhang, J.; Shao, F.; Li, Y.; Cui, H.; Chen, L.; Li, H.; Zou, Y.; Long, C.; Lan, L.; Chai, J.; et al. A Pseudomonas syringae effector inactivates MAPKs to suppress PAMP-induced immunity in plants. Cell Host Microbe 2007, 1, 175-185. [CrossRef] [PubMed]

164. Teper, D.; Girija, A.M.; Bosis, E.; Popov, G.; Savidor, A.; Sessa, G. The Xanthomonas euvesicatoria type III effector XopAU is an active protein kinase that manipulates plant MAP kinase signaling. PLoS Pathog. 2018, 14, e1006880. [CrossRef]

165. Qin, J.; Zhou, X.; Sun, L.; Wang, K.; Yang, F.; Liao, H.; Rong, W.; Yin, J.; Chen, H.; Chen, X.; et al. The Xanthomonas effector XopK harbours E3 ubiquitin-ligase activity that is required for virulence. New Phytol. 2018, 220, 219-231. [CrossRef] [PubMed]

166. Kim, J.-G.; Stork, W.; Mudgett, M.B. Xanthomonas type III effector XopD desumoylates tomato transcription factor SlERF4 to suppress ethylene responses and promote pathogen growth. Cell Host Microbe 2013, 13, 143-154. [CrossRef] [PubMed]

167. Pruneda, J.N.; Durkin, C.H.; Geurink, P.P.; Ovaa, H.; Santhanam, B.; Holden, D.W.; Komander, D. The molecular basis for ubiquitin and ubiquitin-like specificities in bacterial effector proteases. Mol. Cell 2016, 63, 261-276. [CrossRef] [PubMed]

168. Tan, L.; Rong, W.; Luo, H.; Chen, Y.; He, C. The Xanthomonas campestris effector protein XopD Xcc8004 triggers plant disease tolerance by targeting DELLA proteins. New Phytol. 2014, 204, 595-608. [CrossRef]

169. Üstün, S.; Börnke, F. Interactions of Xanthomonas type-III effector proteins with the plant ubiquitin and ubiquitin-like pathways. Front. Plant Sci. 2014, 5. [CrossRef]

170. Cheong, M.S.; Kirik, A.; Kim, J.-G.; Frame, K.; Kirik, V.; Mudgett, M.B. AvrBsT acetylates Arabidopsis ACIP1, a protein that associates with microtubules and is required for immunity. PLoS Pathog. 2014, 10, e1003952. [CrossRef]

171. Szczesny, R.; Büttner, D.; Escolar, L.; Schulze, S.; Seiferth, A.; Bonas, U. Suppression of the AvrBs1-specific hypersensitive response by the YopJ effector homolog AvrBsT from Xanthomonas depends on a SNF1-related kinase. New Phytol. 2010, 187, 1058-1074. [CrossRef]

172. Roden, J.; Eardley, L.; Hotson, A.; Cao, Y.; Mudgett, M.B. Characterization of the Xanthomonas AvrXv4 effector, a SUMO protease translocated into plant cells. Mol. Plant Microbe Interact. 2004, 17, 633-643. [CrossRef]

173. Chen, H.; Chen, J.; Li, M.; Chang, M.; Xu, K.; Shang, Z.; Zhao, Y.; Palmer, I.; Zhang, Y.; McGill, J.; et al. A bacterial type III effector targets the master regulator of salicylic acid signaling, NPR1, to subvert plant immunity. Cell Host Microbe 2017, 22, 777-788.e7. [CrossRef]

174. Li, L.; Kim, P.; Yu, L.; Cai, G.; Chen, S.; Alfano, J.R.; Zhou, J.-M. Activation-dependent destruction of a co-receptor by a Pseudomonas syringae effector dampens plant immunity. Cell Host Microbe 2016, 20, 504-514. [CrossRef]

175. Macho, A.P.; Zipfel, C. Targeting of plant pattern recognition receptor-triggered immunity by bacterial type-III secretion system effectors. Curr. Opin. Microbiol. 2015, 23, 14-22. [CrossRef] [PubMed]

176. Macho, A.P.; Schwessinger, B.; Ntoukakis, V.; Brutus, A.; Segonzac, C.; Roy, S.; Kadota, Y.; Oh, M.-H.; Sklenar, J.; Derbyshire, P.; et al. A bacterial tyrosine phosphatase inhibits plant pattern recognition receptor activation. Science 2014, 343, 1509-1512. [CrossRef] [PubMed]

177. Chung, E.-H.; El-Kasmi, F.; He, Y.; Loehr, A.; Dangl, J.L. A plant phosphoswitch platform repeatedly targeted by type III effector proteins regulates the output of both tiers of plant immune receptors. Cell Host Microbe 2014, 16, 484-494. [CrossRef] [PubMed]

178. Ray, S.K.; Macoy, D.M.; Kim, W.-Y.; Lee, S.Y.; Kim, M.G. Role of RIN4 in Regulating PAMP-triggered immunity and effectortriggered immunity: Current status and future perspectives. Mol. Cells 2019, 42, 503-511. [CrossRef]

179. Lee, D.; Bourdais, G.; Yu, G.; Robatzek, S.; Coaker, G. Phosphorylation of the plant immune regulator RPM1-interacting protein4 enhances plant plasma membrane H+-ATPase activity and inhibits flagellin-triggered immune responses in Arabidopsis. Plant Cell 2015, 27, 2042-2056. [CrossRef] [PubMed]

180. Liu, J.; Elmore, J.M.; Lin, Z.-J.D.; Coaker, G. A receptor-like cytoplasmic kinase phosphorylates the host target RIN4, leading to the activation of a plant innate immune receptor. Cell Host Microbe 2011, 9, 137-146. [CrossRef]

181. Coaker, G.; Falick, A.; Staskawicz, B. Activation of a phytopathogenic bacterial effector protein by a eukaryotic cyclophilin. Science 2005, 308, 548-550. [CrossRef]

182. Li, M.; Ma, X.; Chiang, Y.-H.; Yadeta, K.A.; Ding, P.; Dong, L.; Zhao, Y.; Li, X.; Yu, Y.; Zhang, L.; et al. Proline isomerization of the immune receptor-interacting protein RIN4 by a cyclophilin inhibits effector-triggered immunity in Arabidopsis. Cell Host Microbe 2014, 16, 473-483. [CrossRef]

183. Mackey, D.; Belkhadir, Y.; Alonso, J.M.; Ecker, J.R.; Dangl, J.L. Arabidopsis RIN4 is a target of the type III virulence effector AvrRpt2 and modulates RPS2-mediated resistance. Cell 2003, 112, 379-389. [CrossRef]

184. Chung, E.-H.; da Cunha, L.; Wu, A.-J.; Gao, Z.; Cherkis, K.; Afzal, A.J.; Mackey, D.; Dangl, J.L. Specific threonine phosphorylation of a host target by two unrelated type III effectors activates a host innate immune receptor in plants. Cell Host Microbe 2011, 9 , 125-136. [CrossRef] [PubMed]

185. Toruño, T.Y.; Shen, M.; Coaker, G.; Mackey, D. Regulated disorder: Posttranslational modifications control the RIN4 plant immune signaling hub. Mol. Plant Microbe Interact. 2018, 32, 56-64. [CrossRef]

186. Sun, X.; Greenwood, D.R.; Templeton, M.D.; Libich, D.S.; McGhie, T.K.; Xue, B.; Yoon, M.; Cui, W.; Kirk, C.A.; Jones, W.T.; et al. The Intrinsically Disordered Structural Platform of the Plant Defence Hub Protein RPM1-interacting protein 4 provides insights into its mode of action in the host-pathogen interface and evolution of the nitrate-induced domain protein family. FEBS J. 2014, 281, 3955-3979. [CrossRef] [PubMed] 
187. Popov, G.; Majhi, B.B.; Sessa, G. Effector gene XopAE of Xanthomonas Euvesicatoria 85-10 is part of an operon and encodes an E3 ubiquitin ligase. J. Bacteriol. 2018, 200. [CrossRef]

188. Tan, C.M.; Li, M.-Y.; Yang, P.-Y.; Chang, S.H.; Ho, Y.-P.; Lin, H.; Deng, W.-L.; Yang, J.-Y. Arabidopsis HFR1 is a potential nuclear substrate regulated by the Xanthomonas type III effector XopD Xcc8004. PLoS ONE 2015, 10, e0117067. [CrossRef]

189. Navarro, L.; Bari, R.; Achard, P.; Lisón, P.; Nemri, A.; Harberd, N.P.; Jones, J.D.G. DELLAs control plant immune responses by modulating the balance of jasmonic acid and salicylic acid signaling. Curr. Biol. 2008, 18, 650-655. [CrossRef] [PubMed]

190. Bos, J.I.B.; Armstrong, M.R.; Gilroy, E.M.; Boevink, P.C.; Hein, I.; Taylor, R.M.; Zhendong, T.; Engelhardt, S.; Vetukuri, R.R.; Harrower, B.; et al. Phytophthora Infestans Effector AVR3a is essential for virulence and manipulates plant immunity by stabilizing host E3 ligase CMPG1. Proc. Natl. Acad. Sci. USA 2010, 107, 9909-9914. [CrossRef]

191. Park, C.-H.; Chen, S.; Shirsekar, G.; Zhou, B.; Khang, C.H.; Songkumarn, P.; Afzal, A.J.; Ning, Y.; Wang, R.; Bellizzi, M.; et al. The Magnaporthe Oryzae effector AvrPiz-t Targets the RING E3 Ubiquitin Ligase APIP6 to suppress pathogen-associated molecular pattern-triggered immunity in rice. Plant Cell 2012, 24, 4748-4762. [CrossRef]

192. Huot, B.; Yao, J.; Montgomery, B.L.; He, S.Y. Growth-defense tradeoffs in plants: A balancing act to optimize fitness. Mol. Plant 2014, 7, 1267-1287. [CrossRef]

193. Tian, D.; Traw, M.B.; Chen, J.Q.; Kreitman, M.; Bergelson, J. Fitness costs of R-gene-mediated resistance in Arabidopsis thaliana. Nature 2003, 423, 74-77. [CrossRef]

194. Herms, D.A.; Mattson, W.J. The dilemma of plants: To grow or defend. Q. Rev. Biol. 1992, 67, 283-335. [CrossRef]

195. Campos, M.L.; Yoshida, Y.; Major, I.T.; de Oliveira Ferreira, D.; Weraduwage, S.M.; Froehlich, J.E.; Johnson, B.F.; Kramer, D.M.; Jander, G.; Sharkey, T.D.; et al. Rewiring of jasmonate and phytochrome B signalling uncouples plant growth-defense tradeoffs. Nat. Commun. 2016, 7. [CrossRef] [PubMed]

196. Eichmann, R.; Schäfer, P. Growth versus Immunity-A Redirection of the Cell Cycle? Curr. Opin. Plant Biol. 2015, 26, 106-112. [CrossRef]

197. Kliebenstein, D.J. False idolatry of the mythical growth versus immunity tradeoff in molecular systems plant pathology. Physiol. Mol. Plant Pathol. 2016, 95, 55-59. [CrossRef]

198. Margalha, L.; Confraria, A.; Baena-González, E. SnRK1 and TOR: Modulating growth-defense trade-offs in plant stress responses. J. Exp. Bot. 2019, 70, 2261-2274. [CrossRef]

199. Dobrenel, T.; Caldana, C.; Hanson, J.; Robaglia, C.; Vincentz, M.; Veit, B.; Meyer, C. TOR Signaling and nutrient sensing. Annu. Rev. Plant Biol. 2016, 67, 261-285. [CrossRef] [PubMed]

200. Robaglia, C.; Thomas, M.; Meyer, C. Sensing nutrient and energy status by SnRK1 and TOR kinases. Curr. Opin. Plant Biol. 2012, 15, 301-307. [CrossRef] [PubMed]

201. Lastdrager, J.; Hanson, J.; Smeekens, S. Sugar Signals and the Control of Plant Growth and Development. J. Exp. Bot. 2014, 65, 799-807. [CrossRef]

202. Nukarinen, E.; Nägele, T.; Pedrotti, L.; Wurzinger, B.; Mair, A.; Landgraf, R.; Börnke, F.; Hanson, J.; Teige, M.; Baena-Gonzalez, E.; et al. Quantitative Phosphoproteomics Reveals the Role of the AMPK Plant Ortholog SnRK1 as a metabolic master regulator under energy deprivation. Sci. Rep. 2016, 6, 31697. [CrossRef]

203. Xiong, Y.; Sheen, J. Novel links in the plant TOR kinase signaling network. Curr. Opin. Plant Biol. 2015, 28, 83-91. [CrossRef] [PubMed]

204. Halford, N.G.; Hardie, D.G. SNF1-related protein kinases: Global regulators of carbon metabolism in plants? Plant Mol. Biol. 1998, 37, 735-748. [CrossRef]

205. Kulik, A.; Wawer, I.; Krzywińska, E.; Bucholc, M.; Dobrowolska, G. SnRK2 protein kinases—Key regulators of plant response to abiotic stresses. OMICS 2011, 15, 859-872. [CrossRef]

206. Baena-González, E.; Sheen, J. Convergent energy and stress signaling. Trends Plant Sci. 2008, 13, 474-482. [CrossRef] [PubMed]

207. Baena-González, E.; Rolland, F.; Thevelein, J.M.; Sheen, J. A central integrator of transcription networks in plant stress and energy signalling. Nature 2007, 448, 938-942. [CrossRef] [PubMed]

208. Hao, L.; Wang, H.; Sunter, G.; Bisaro, D.M. Geminivirus AL2 and L2 proteins interact with and inactivate SNF1 kinase. Plant Cell 2003, 15, 1034-1048. [CrossRef] [PubMed]

209. Lin, C.-R.; Lee, K.-W.; Chen, C.-Y.; Hong, Y.-F.; Chen, J.-L.; Lu, C.-A.; Chen, K.-T.; Ho, T.-H.D.; Yu, S.-M. SnRK1A-Interacting Negative Regulators Modulate the Nutrient Starvation Signaling Sensor SnRK1 in source-sink communication in cereal seedlings under abiotic stress. Plant Cell 2014, 26, 808-827. [CrossRef] [PubMed]

210. Schwachtje, J.; Minchin, P.E.H.; Jahnke, S.; van Dongen, J.T.; Schittko, U.; Baldwin, I.T. SNF1-related kinases allow plants to tolerate herbivory by allocating carbon to roots. Proc. Natl. Acad. Sci. USA 2006, 103, 12935-12940. [CrossRef]

211. Sheen, J. Master regulators in plant glucose signaling networks. J. Plant Biol. 2014, 57, 67-79. [CrossRef] [PubMed]

212. Polge, C.; Jossier, M.; Crozet, P.; Gissot, L.; Thomas, M. $\beta$-subunits of the SnRK1 Complexes Share a Common Ancestral Function Together with Expression and Function Specificities; Physical interaction with nitrate reductase specifically occurs via AKINß1-subunit. Plant Physiol. 2008, 148, 1570-1582. [CrossRef]

213. Sugden, C.; Donaghy, P.G.; Halford, N.G.; Hardie, D.G. Two SNF1-Related Protein Kinases from Spinach Leaf Phosphorylate and Inactivate 3-Hydroxy-3-methylglutaryl-coenzyme a reductase, nitrate reductase, and sucrose phosphate synthase in vitro. Plant Physiol. 1999, 120, 257-274. [CrossRef] 
214. Xiong, Y.; McCormack, M.; Li, L.; Hall, Q.; Xiang, C.; Sheen, J. Glc-TOR signalling leads transcriptome reprogramming and meristem activation. Nature 2013, 496, 181-186. [CrossRef]

215. Chen, G.-H.; Liu, M.-J.; Xiong, Y.; Sheen, J.; Wu, S.-H. TOR and RPS6 transmit light signals to enhance protein translation in deetiolating Arabidopsis seedlings. Proc. Natl. Acad. Sci. USA 2018, 115, 12823-12828. [CrossRef] [PubMed]

216. Xiong, Y.; Sheen, J. Rapamycin and glucose-target of rapamycin (TOR) protein signaling in plants. J. Biol. Chem. 2012, 287, 2836-2842. [CrossRef] [PubMed]

217. Wang, P.; Zhao, Y.; Li, Z.; Hsu, C.-C.; Liu, X.; Fu, L.; Hou, Y.-J.; Du, Y.; Xie, S.; Zhang, C.; et al. Reciprocal regulation of the TOR kinase and ABA receptor balances plant growth and stress response. Mol. Cell 2018, 69, 100-112.e6. [CrossRef]

218. Jamsheer, M.K.; Jindal, S.; Laxmi, A. Evolution of TOR-SnRK dynamics in green plants and its integration with phytohormone signaling networks. J. Exp. Bot. 2019, 70, 2239-2259. [CrossRef]

219. Weiste, C.; Pedrotti, L.; Selvanayagam, J.; Muralidhara, P.; Fröschel, C.; Novák, O.; Ljung, K.; Hanson, J.; Dröge-Laser, W. The Arabidopsis BZIP11 transcription factor links low-energy signalling to auxin-mediated control of primary root growth. PLoS Genet. 2017, 13, e1006607. [CrossRef]

220. Schepetilnikov, M.; Makarian, J.; Srour, O.; Geldreich, A.; Yang, Z.; Chicher, J.; Hammann, P.; Ryabova, L.A. GTPase ROP2 binds and promotes activation of target of rapamycin, TOR, in response to auxin. EMBO J. 2017, 36, 886-903. [CrossRef] [PubMed]

221. Hey, S.; Mayerhofer, H.; Halford, N.G.; Dickinson, J.R. DNA Sequences from Arabidopsis, which encode protein kinases and function as upstream regulators of Snf1 in yeast. J. Biol. Chem. 2007, 282, 10472-10479. [CrossRef]

222. Rodrigues, A.; Adamo, M.; Crozet, P.; Margalha, L.; Confraria, A.; Martinho, C.; Elias, A.; Rabissi, A.; Lumbreras, V.; GonzálezGuzmán, M.; et al. ABI1 and PP2CA phosphatases are negative regulators of Snf1-related protein kinase1 signaling in Arabidopsis. Plant Cell 2013, 25, 3871-3884. [CrossRef]

223. Aznar, N.R.; Consolo, V.F.; Salerno, G.L.; Martínez-Noël, G.M.A. TOR signaling downregulation increases resistance to the cereal killer fusarium graminearum. Plant Signal. Behav. 2018, 13, e1414120. [CrossRef]

224. Vleesschauwer, D.D.; Filipe, O.; Hoffman, G.; Seifi, H.S.; Haeck, A.; Canlas, P.; Bockhaven, J.V.; Waele, E.D.; Demeestere, K.; Ronald, P.; et al. Target of rapamycin signaling orchestrates growth-defense trade-offs in plants. New Phytol. 2018, 217, 305-319. [CrossRef] [PubMed]

225. Filipe, O.; De Vleesschauwer, D.; Haeck, A.; Demeestere, K.; Höfte, M. The energy sensor OsSnRK1a confers broad-spectrum disease resistance in rice. Sci. Rep. 2018, 8, 3864. [CrossRef] [PubMed]

226. Shen, W.; Bobay, B.G.; Greeley, L.A.; Reyes, M.I.; Rajabu, C.A.; Blackburn, R.K.; Dallas, M.B.; Goshe, M.B.; Ascencio-Ibáñez, J.T.; Hanley-Bowdoin, L. Sucrose Nonfermenting 1-Related Protein Kinase 1 Phosphorylates a geminivirus rep protein to impair viral replication and infection. Plant Physiol. 2018, 178, 372-389. [CrossRef]

227. Janse van Rensburg, H.C.; Van den Ende, W.; Signorelli, S. Autophagy in plants: Both a puppet and a puppet master of sugars. Front. Plant Sci. 2019, 10, 14. [CrossRef]

228. Zhang, Y.; Primavesi, L.F.; Jhurreea, D.; Andralojc, P.J.; Mitchell, R.A.C.; Powers, S.J.; Schluepmann, H.; Delatte, T.; Wingler, A.; Paul, M.J. Inhibition of SNF1-related protein kinase1 activity and regulation of metabolic pathways by trehalose-6-phosphate. Plant Physiol. 2009, 149, 1860-1871. [CrossRef]

229. Han, X.; Zhang, L.; Zhao, L.; Xue, P.; Qi, T.; Zhang, C.; Yuan, H.; Zhou, L.; Wang, D.; Qiu, J.; et al. SnRK1 Phosphorylates and destabilizes WRKY3 to enhance barley immunity to powdery mildew. Plant Commun. 2020, 1. [CrossRef]

230. Lee, H.-J.; Park, Y.-J.; Seo, P.J.; Kim, J.-H.; Sim, H.-J.; Kim, S.-G.; Park, C.-M. Systemic immunity requires SnRK2.8-mediated nuclear import of NPR1 in Arabidopsis. Plant Cell 2015, 27, 3425-3438. [CrossRef] [PubMed]

231. Mou, Z.; Fan, W.; Dong, X. Inducers of plant systemic acquired resistance regulate NPR1 function through redox changes. Cell 2003, 113, 935-944. [CrossRef]

232. Tada, Y.; Spoel, S.H.; Pajerowska-Mukhtar, K.; Mou, Z.; Song, J.; Wang, C.; Zuo, J.; Dong, X. Plant immunity requires conformational charges of NPR1 via S-nitrosylation and thioredoxins. Science 2008, 321, 952-956. [CrossRef]

233. Jiang, C.; Hei, R.; Yang, Y.; Zhang, S.; Wang, Q.; Wang, W.; Zhang, Q.; Yan, M.; Zhu, G.; Huang, P.; et al. An orphan protein of Fusarium graminearum modulates host immunity by mediating proteasomal degradation of TaSnRK1 $\alpha$. Nat. Commun. 2020, 11. [CrossRef]

234. Schepetilnikov, M.; Kobayashi, K.; Geldreich, A.; Caranta, C.; Robaglia, C.; Keller, M.; Ryabova, L.A. Viral factor TAV recruits TOR/S6K1 signalling to activate reinitiation after long ORF translation. EMBO J. 2011, 30, 1343-1356. [CrossRef]

235. Popa, C.; Li, L.; Gil, S.; Tatjer, L.; Hashii, K.; Tabuchi, M.; Coll, N.S.; Ariño, J.; Valls, M. The effector AWR5 from the plant pathogen ralstonia solanacearum is an inhibitor of the TOR signalling pathway. Sci. Rep. 2016, 6, 27058. [CrossRef]

236. Chang, Y.-Y.; Neufeld, T.P. An Atg1/Atg13 complex with multiple roles in TOR-mediated autophagy regulation. Mol. Biol. Cell 2009, 20, 2004-2014. [CrossRef] [PubMed]

237. Soto-Burgos, J.; Bassham, D.C. SnRK1 activates autophagy via the TOR signaling pathway in Arabidopsis thaliana. PLoS ONE 2017, 12, e0182591. [CrossRef]

238. Lai, Z.; Wang, F.; Zheng, Z.; Fan, B.; Chen, Z. A critical role of autophagy in plant resistance to necrotrophic fungal pathogens. Plant J. 2011, 66, 953-968. [CrossRef] [PubMed]

239. Leary, A.Y.; Sanguankiattichai, N.; Duggan, C.; Tumtas, Y.; Pandey, P.; Segretin, M.E.; Salguero Linares, J.; Savage, Z.D.; Yow, R.J.; Bozkurt, T.O. Modulation of plant autophagy during pathogen attack. J. Exp. Bot. 2018, 69, 1325-1333. [CrossRef] 
240. Crozet, P.; Margalha, L.; Butowt, R.; Fernandes, N.; Elias, C.A.; Orosa, B.; Tomanov, K.; Teige, M.; Bachmair, A.; Sadanandom, A.; et al. SUMOylation represses SnRK1 signaling in Arabidopsis. Plant J. 2016, 85, 120-133. [CrossRef]

241. Ulrich, H.D. The fast-growing business of SUMO chains. Mol. Cell 2008, 32, 301-305. [CrossRef]

242. Nietzsche, M.; Landgraf, R.; Tohge, T.; Börnke, F. A protein-protein interaction network linking the energy-sensor kinase SnRK1 to multiple signaling pathways in Arabidopsis thaliana. Curr. Plant Biol. 2016, 5, 36-44. [CrossRef]

243. Zentella, R.; Zhang, Z.-L.; Park, M.; Thomas, S.G.; Endo, A.; Murase, K.; Fleet, C.M.; Jikumaru, Y.; Nambara, E.; Kamiya, Y.; et al. Global analysis of DELLA direct targets in early gibberellin signaling in Arabidopsis. Plant Cell 2007, 19, 3037-3057. [CrossRef] [PubMed]

244. Li, Y.; Yang, Y.; Hu, Y.; Liu, H.; He, M.; Yang, Z.; Kong, F.; Liu, X.; Hou, X. DELLA and EDS1 form a feedback regulatory module to fine-tune plant growth-defense tradeoff in Arabidopsis. Mol. Plant 2019, 12, 1485-1498. [CrossRef] [PubMed]

245. Achard, P.; Cheng, H.; Grauwe, L.D.; Decat, J.; Schoutteten, H.; Moritz, T.; Straeten, D.V.D.; Peng, J.; Harberd, N.P. Integration of plant responses to environmentally activated phytohormonal signals. Science 2006, 311, 91-94. [CrossRef] [PubMed]

246. Blanco-Touriñán, N.; Serrano-Mislata, A.; Alabadí, D. Regulation of DELLA proteins by post-translational modifications. Plant Cell Physiol. 2020, 61, 1891-1901. [CrossRef]

247. Claeys, H.; De Bodt, S.; Inzé, D. Gibberellins and DELLAs: Central nodes in growth regulatory networks. Trends Plant Sci. 2014, 19, 231-239. [CrossRef]

248. Dill, A.; Thomas, S.G.; Hu, J.; Steber, C.M.; Sun, T.-P. The Arabidopsis F-Box Protein SLEEPY1 targets gibberellin signaling repressors for gibberellin-induced degradation. Plant Cell 2004, 16, 1392-1405. [CrossRef]

249. Fu, X.; Richards, D.E.; Fleck, B.; Xie, D.; Burton, N.; Harberd, N.P. The Arabidopsis Mutant Sleepy1gar2-1 protein promotes plant growth by increasing the affinity of the SCFSLY1 E3 ubiquitin ligase for DELLA protein substrates. Plant Cell 2004, 16, 1406-1418. [CrossRef]

250. Griffiths, J.; Murase, K.; Rieu, I.; Zentella, R.; Zhang, Z.-L.; Powers, S.J.; Gong, F.; Phillips, A.L.; Hedden, P.; Sun, T.; et al. Genetic characterization and functional analysis of the GID1 gibberellin receptors in Arabidopsis. Plant Cell 2006, 18, 3399-3414. [CrossRef] [PubMed]

251. Murase, K.; Hirano, Y.; Sun, T.; Hakoshima, T. Gibberellin-induced DELLA recognition by the gibberellin receptor GID1. Nature 2008, 456, 459-463. [CrossRef] [PubMed]

252. Sun, T.-P.; Gubler, F. Molecular mechanism of gibberellin signaling in plants. Annu. Rev. Plant Biol. 2004, 55, 197-223. [CrossRef]

253. Ueguchi-Tanaka, M.; Ashikari, M.; Nakajima, M.; Itoh, H.; Katoh, E.; Kobayashi, M.; Chow, T.; Hsing, Y.C.; Kitano, H.; Yamaguchi, I.; et al. Gibberellin insensitive dwarf1 encodes a soluble receptor for gibberellin. Nature 2005, 437, 693-698. [CrossRef]

254. Willige, B.C.; Ghosh, S.; Nill, C.; Zourelidou, M.; Dohmann, E.M.N.; Maier, A.; Schwechheimer, C. The DELLA domain of GA insensitive mediates the interaction with the GA insensitive dwarf1A gibberellin receptor of Arabidopsis. Plant Cell 2007, 19, 1209-1220. [CrossRef]

255. Curaba, J.; Moritz, T.; Blervaque, R.; Parcy, F.; Raz, V.; Herzog, M.; Vachon, G. AtGA3ox2, a key gene responsible for bioactive gibberellin biosynthesis, is regulated during embryogenesis by leafy cotyledon2 and fusca3 in Arabidopsis. Plant Physiol. 2004, 136, 3660-3669. [CrossRef]

256. Gazzarrini, S.; Tsuchiya, Y.; Lumba, S.; Okamoto, M.; McCourt, P. The transcription factor fusca3 controls developmental timing in Arabidopsis through the hormones gibberellin and abscisic acid. Dev. Cell 2004, 7, 373-385. [CrossRef]

257. Tsai, A.Y.-L.; Gazzarrini, S. AKIN10 and FUSCA3 interact to control lateral organ development and phase transitions in Arabidopsis. Plant J. 2012, 69, 809-821. [CrossRef]

258. Zhang, Y.; Zhang, Y.; McFarlane, H.E.; Obata, T.; Richter, A.S.; Lohse, M.; Grimm, B.; Persson, S.; Fernie, A.R.; Giavalisco, P. Inhibition of TOR represses nutrient consumption, which improves greening after extended periods of etiolation1. Plant Physiol. 2018, 178, 101-117. [CrossRef] [PubMed]

259. Hou, X.; Hu, W.-W.; Shen, L.; Lee, L.Y.C.; Tao, Z.; Han, J.-H.; Yu, H. Global identification of DELLA target genes during Arabidopsis flower development. Plant Physiol. 2008, 147, 1126-1142. [CrossRef]

260. Vleesschauwer, D.D.; Seifi, H.S.; Filipe, O.; Haeck, A.; Huu, S.N.; Demeestere, K.; Höfte, M. The DELLA protein SLR1 integrates and amplifies salicylic acid- and jasmonic acid-dependent innate immunity in rice. Plant Physiol. 2016, 170, 1831-1847. [CrossRef] [PubMed]

261. Li, X.; Liu, W.; Li, B.; Liu, G.; Wei, Y.; He, C.; Shi, H. Identification and functional analysis of cassava DELLA proteins in plant disease resistance against cassava bacterial blight. Plant Physiol. Biochem. 2018, 124, 70-76. [CrossRef] [PubMed]

262. Conti, L.; Nelis, S.; Zhang, C.; Woodcock, A.; Swarup, R.; Galbiati, M.; Tonelli, C.; Napier, R.; Hedden, P.; Bennett, M.; et al. Small ubiquitin-like modifier protein SUMO enables plants to control growth independently of the phytohormone gibberellin. Dev. Cell 2014, 28, 102-110. [CrossRef]

263. Nelis, S.; Conti, L.; Zhang, C.; Sadanandom, A. A functional small ubiquitin-like modifier (SUMO) interacting motif (SIM) in the Gibberellin Hormone Receptor GID1 is conserved in cereal crops and disrupting this motif does not abolish hormone dependency of the DELLA-GID1 interaction. Plant Signal. Behav. 2015, 10. [CrossRef] [PubMed]

264. Campanaro, A.; Battaglia, R.; Galbiati, M.; Sadanandom, A.; Tonelli, C.; Conti, L. SUMO proteases OTS1 and 2 control filament elongation through a DELLA-dependent mechanism. Plant Reprod. 2016, 29, 287-290. [CrossRef] 
265. Gonçalves, N.M.; Fernandes, T.; Nunes, C.; Rosa, M.T.G.; Matiolli, C.C.; Rodrigues, M.A.A.; Barros, P.M.; Oliveira, M.M.; Abreu, I.A. SUMOylation of rice DELLA SLR1 modulates transcriptional responses and improves yield under salt stress. bioRxiv 2020. [CrossRef]

266. Dai, C.; Xue, H.-W. Rice Early Flowering1, a CKI, Phosphorylates DELLA Protein SLR1 to negatively regulate gibberellin signalling. EMBO J. 2010, 29, 1916-1927. [CrossRef] [PubMed]

267. Qin, Q.; Wang, W.; Guo, X.; Yue, J.; Huang, Y.; Xu, X.; Li, J.; Hou, S. Arabidopsis DELLA protein degradation is controlled by a type-one protein phosphatase, TOPP4. PLoS Genet. 2014, 10, e1004464. [CrossRef]

268. Wild, M.; Davière, J.-M.; Cheminant, S.; Regnault, T.; Baumberger, N.; Heintz, D.; Baltz, R.; Genschik, P.; Achard, P. The Arabidopsis DELLA RGA-LIKE3 is a direct target of MYC2 and modulates jasmonate signaling responses. Plant Cell 2012, 24, 3307-3319. [CrossRef] [PubMed]

269. Hou, X.; Lee, L.Y.C.; Xia, K.; Yan, Y.; Yu, H. DELLAs modulate jasmonate signaling via competitive binding to JAZs. Dev. Cell 2010, 19, 884-894. [CrossRef]

270. Yang, D.-L.; Yao, J.; Mei, C.-S.; Tong, X.-H.; Zeng, L.-J.; Li, Q.; Xiao, L.-T.; Sun, T.; Li, J.; Deng, X.-W.; et al. Plant hormone jasmonate prioritizes defense over growth by interfering with gibberellin signaling cascade. Proc. Natl. Acad. Sci. USA 2012, 109, E1192-E1200. [CrossRef] [PubMed]

271. Liu, X.-J.; An, X.-H.; Liu, X.; Hu, D.-G.; Wang, X.-F.; You, C.-X.; Hao, Y.-J. MdSnRK1.1 interacts with MdJAZ18 to regulate sucrose-induced anthocyanin and proanthocyanidin accumulation in apple. J. Exp. Bot. 2017, 68, 2977-2990. [CrossRef]

272. Coello, P.; Hey, S.J.; Halford, N.G. The sucrose non-fermenting-1-related (SnRK) family of protein kinases: Potential for manipulation to improve stress tolerance and increase yield. J. Exp. Bot. 2011, 62, 883-893. [CrossRef]

273. Karasov, T.L.; Chae, E.; Herman, J.J.; Bergelson, J. Mechanisms to mitigate the trade-off between growth and defense. Plant Cell 2017, 29, 666-680. [CrossRef]

274. Walters, D.; Heil, M. Costs and trade-offs associated with induced resistance. Physiol. Mol. Plant Pathol. 2007, 71, 3-17. [CrossRef]

275. de Vega, D.; Newton, A.C.; Sadanandom, A. Post-translational modifications in priming the plant immune system: Ripe for exploitation? FEBS Lett. 2018, 592, 1929-1936. [CrossRef]

276. Luna, E.; van Hulten, M.; Zhang, Y.; Berkowitz, O.; López, A.; Pétriacq, P.; Sellwood, M.A.; Chen, B.; Burrell, M.; van de Meene, A.; et al. Plant perception of $\beta$-aminobutyric acid is mediated by an aspartyl-TRNA synthetase. Nat. Chem. Biol. 2014, 10, 450-456. [CrossRef] [PubMed]

277. Gent, L.; Forde, B.G. How do plants sense their nitrogen status? J. Exp. Bot. 2017, 68, 2531-2539. [CrossRef]

278. Yang, D.-L.; Yang, Y.; He, Z. Roles of plant hormones and their interplay in rice immunity. Mol. Plant 2013, 6, 675-685. [CrossRef] [PubMed]

279. Beckers, G.J.M.; Spoel, S.H. Fine-tuning plant defence signalling: Salicylate versus jasmonate. Plant Biol. 2006, 8, 1-10. [CrossRef] [PubMed]

280. Li, X.; Yang, D.-L.; Sun, L.; Li, Q.; Mao, B.; He, Z. The systemic acquired resistance regulator OsNPR1 attenuates growth by repressing auxin signaling through promoting IAA-amido synthase expression1. Plant Physiol. 2016, 172, 546-558. [CrossRef] [PubMed]

281. Wang, D.; Pajerowska-Mukhtar, K.; Culler, A.H.; Dong, X. Salicylic acid inhibits pathogen growth in plants through repression of the auxin signaling pathway. Curr. Biol. 2007, 17, 1784-1790. [CrossRef] [PubMed]

282. Zhang, Y.; Turner, J.G. Wound-induced endogenous jasmonates stunt plant growth by inhibiting mitosis. PLoS ONE 2008, 3 , e3699. [CrossRef]

283. Garavaglia, B.S.; Thomas, L.; Gottig, N.; Zimaro, T.; Garofalo, C.G.; Gehring, C.; Ottado, J. Shedding light on the role of photosynthesis in pathogen colonization and host defense. Commun. Integr. Biol. 2010, 3, 382-384. [CrossRef] [PubMed]

284. Albrecht, C.; Boutrot, F.; Segonzac, C.; Schwessinger, B.; Gimenez-Ibanez, S.; Chinchilla, D.; Rathjen, J.P.; de Vries, S.C.; Zipfel, C. Brassinosteroids inhibit pathogen-associated molecular pattern-triggered immune signaling independent of the receptor kinase BAK1. Proc. Natl. Acad. Sci. USA 2012, 109, 303-308. [CrossRef] [PubMed]

285. Nakashita, H.; Yasuda, M.; Nitta, T.; Asami, T.; Fujioka, S.; Arai, Y.; Sekimata, K.; Takatsuto, S.; Yamaguchi, I.; Yoshida, S. Brassinosteroid functions in a broad range of disease resistance in tobacco and rice. Plant J. 2003, 33, 887-898. [CrossRef]

286. Zhang, D.-W.; Deng, X.-G.; Fu, F.-Q.; Lin, H.-H. Induction of plant virus defense response by brassinosteroids and brassinosteroid signaling in Arabidopsis thaliana. Planta 2015, 241, 875-885. [CrossRef]

287. Miyaji, T.; Yamagami, A.; Kume, N.; Sakuta, M.; Osada, H.; Asami, T.; Arimoto, Y.; Nakano, T. Brassinosteroid-related transcription factor BIL1/BZR1 increases plant resistance to insect feeding. Biosci. Biotechnol. Biochem. 2014, 78, 960-968. [CrossRef] [PubMed]

288. Lin, W.; Lu, D.; Gao, X.; Jiang, S.; Ma, X.; Wang, Z.; Mengiste, T.; He, P.; Shan, L. Inverse Modulation of Plant Immune and Brassinosteroid Signaling Pathways by the Receptor-like cytoplasmic kinase BIK1. Proc. Natl. Acad. Sci. USA 2013, 110, 12114-12119. [CrossRef]

289. Jaillais, Y.; Belkhadir, Y.; Balsemão-Pires, E.; Dangl, J.L.; Chory, J. Extracellular leucine-rich repeats as a platform for receptor/coreceptor complex formation. Proc. Natl. Acad. Sci. USA 2011, 108, 8503-8507. [CrossRef]

290. Kim, S.-R.; Ramos, J.M.; Hizon, R.J.M.; Ashikari, M.; Virk, P.S.; Torres, E.A.; Nissila, E.; Jena, K.K. Introgression of a functional epigenetic OsSPL 14 WFP allele into elite indica rice genomes greatly improved panicle traits and grain yield. Sci. Rep. 2018, 8, 3833. [CrossRef] 
291. Wang, J.; Zhou, L.; Shi, H.; Chern, M.; Yu, H.; Yi, H.; He, M.; Yin, J.; Zhu, X.; Li, Y.; et al. A single transcription factor promotes both yield and immunity in rice. Science 2018, 361, 1026-1028. [CrossRef]

292. Lu, Z.; Yu, H.; Xiong, G.; Wang, J.; Jiao, Y.; Liu, G.; Jing, Y.; Meng, X.; Hu, X.; Qian, Q.; et al. Genome-wide binding analysis of the transcription activator ideal plant architecture1 reveals a complex network regulating rice plant architecture. Plant Cell 2013, 25, 3743-3759. [CrossRef]

293. Wang, J.; Yu, H.; Xiong, G.; Lu, Z.; Jiao, Y.; Meng, X.; Liu, G.; Chen, X.; Wang, Y.; Li, J. Tissue-specific ubiquitination by IPA1 interacting protein1 modulates IPA1 protein levels to regulate plant architecture in rice. Plant Cell 2017, 29, 697-707. [CrossRef]

294. Jiao, Y.; Wang, Y.; Xue, D.; Wang, J.; Yan, M.; Liu, G.; Dong, G.; Zeng, D.; Lu, Z.; Zhu, X.; et al. Regulation of OsSPL14 by OsmiR156 defines ideal plant architecture in rice. Nat. Genet. 2010, 42, 541-544. [CrossRef] [PubMed]

295. Zhang, L.; Yu, H.; Ma, B.; Liu, G.; Wang, J.; Wang, J.; Gao, R.; Li, J.; Liu, J.; Xu, J.; et al. A natural tandem array alleviates epigenetic repression of IPA1 and leads to superior yielding rice. Nat. Commun. 2017, 8, 14789. [CrossRef] [PubMed]

296. Liu, M.; Shi, Z.; Zhang, X.; Wang, M.; Zhang, L.; Zheng, K.; Liu, J.; Hu, X.; Di, C.; Qian, Q.; et al. Inducible overexpression of ideal plant architecture1 improves both yield and disease resistance in rice. Nat. Plants 2019, 5, 389-400. [CrossRef]

297. Birkenbihl, R.P.; Jach, G.; Saedler, H.; Huijser, P. Functional dissection of the plant-specific SBP-domain: Overlap of the DNAbinding and nuclear localization domains. J. Mol. Biol. 2005, 352, 585-596. [CrossRef]

298. Cao, J.; Liu, K.; Song, W. Pleiotropic function of SQUAMOSA PROMOTER-BINDING PROTEIN-BOX gene TaSPL14 on plant architecture of wheat. Planta 2020, 253, 44. [CrossRef]

299. Wei, H.; Zhao, Y.; Xie, Y.; Wang, H. Exploiting SPL genes to improve maize plant architecture tailored for high-density planting. J. Exp. Bot. 2018, 69, 4675-4688. [CrossRef]

300. Xie, Y.; Liu, Y.; Ma, M.; Zhou, Q.; Zhao, Y.; Zhao, B.; Wang, B.; Wei, H.; Wang, H. Arabidopsis FHY3 and FAR1 integrate light and strigolactone signaling to regulate branching. Nat. Commun. 2020, 11, 1955. [CrossRef]

301. Yin, H.; Hong, G.; Li, L.; Zhang, X.; Kong, Y.; Sun, Z.; Li, J.; Chen, J.; He, Y. MiR156/SPL9 regulates reactive oxygen species accumulation and immune response in Arabidopsis thaliana. Phytopathology 2018, 109, 632-642. [CrossRef]

302. Olsen, K.M.; Wendel, J.F. A Bountiful harvest: Genomic insights into crop domestication phenotypes. Annu. Rev. Plant Biol. 2013, 64, 47-70. [CrossRef]

303. Brown, J.K.M. Yield penalties of disease resistance in crops. Curr. Opin. Plant Biol. 2002, 5, 339-344. [CrossRef]

304. Ning, Y.; Liu, W.; Wang, G.-L. Balancing immunity and yield in crop plants. Trends Plant Sci. 2017, 22, 1069-1079. [CrossRef]

305. Da Silva, A.C.; de Lima, M.F.; Eloy, N.B.; Thiebaut, F.; Montessoro, P.; Hemerly, A.S.; Ferreira, P.C.G. The yin and yang in plant breeding: The trade-off between plant growth yield and tolerance to stresses. Biotechnol. Res. Innov. 2019, 3, 73-79. [CrossRef]

306. Schenke, D.; Cai, D. Applications of CRISPR/Cas to Improve Crop Disease Resistance: Beyond inactivation of susceptibility factors. iScience 2020, 23. [CrossRef]

307. Chujo, T.; Miyamoto, K.; Ogawa, S.; Masuda, Y.; Shimizu, T.; Kishi-Kaboshi, M.; Takahashi, A.; Nishizawa, Y.; Minami, E.; Nojiri, H.; et al. Overexpression of phosphomimic mutated OsWRKY53 leads to enhanced blast resistance in rice. PLoS ONE 2014, 9, e98737. [CrossRef]

308. Pearlman, S.M.; Serber, Z.; Ferrell, J.E. A mechanism for the evolution of phosphorylation sites. Cell 2011, 147, 934-946. [CrossRef]

309. Mansueto, L.; Fuentes, R.R.; Borja, F.N.; Detras, J.; Abriol-Santos, J.M.; Chebotarov, D.; Sanciangco, M.; Palis, K.; Copetti, D.; Poliakov, A.; et al. Rice SNP-seek database update: New SNPs, indels, and queries. Nucleic Acids Res. 2017, 45, D1075-D1081. [CrossRef]

310. Tareke Woldegiorgis, S.; Wang, S.; He, Y.; Xu, Z.; Chen, L.; Tao, H.; Zhang, Y.; Zou, Y.; Harrison, A.; Zhang, L.; et al. Rice stress-resistant SNP database. Rice 2019, 12. [CrossRef]

311. Ferro, A.M.; Ramos, P.; Guerreiro, O.; Jerónimo, E.; Pires, I.; Capel, C.; Capel, J.; Lozano, R.; Duarte, M.F.; Oliveira, M.M.; et al Impact of novel SNPs identified in cynara cardunculus genes on functionality of proteins regulating phenylpropanoid pathway and their association with biological activities. BMC Genom. 2017, 18, 183. [CrossRef]

312. Kim, Y.; Kang, C.; Min, B.; Yi, G.-S. Detection and analysis of disease-associated single nucleotide polymorphism influencing post-translational modification. BMC Med. Genom. 2015, 8 (Suppl 2), S7. [CrossRef]

313. Yang, Y.; Peng, X.; Ying, P.; Tian, J.; Li, J.; Ke, J.; Zhu, Y.; Gong, Y.; Zou, D.; Yang, N.; et al. AWESOME: A database of SNPs that affect protein post-translational modifications. Nucleic Acids Res. 2019, 47, D874-D880. [CrossRef]

314. National Academies of Sciences, Engineering and Medicine. Genetically Engineered Crops: Experiences and Prospects; The National Academies Press: Washington, DC, USA, 2016. [CrossRef]

315. Simó, C.; Ibáñez, C.; Valdés, A.; Cifuentes, A.; García-Cañas, V. Metabolomics of genetically modified crops. Int. J. Mol. Sci. 2014, 15, 18941-18966. [CrossRef]

316. Spoel, S.H. Orchestrating the proteome with post-translational modifications. J. Exp. Bot. 2018, 69, 4499-4503. [CrossRef]

317. Yang, B. Grand challenges in genome editing in plants. Front. Genome Ed. 2020, 2. [CrossRef]

318. Gaudelli, N.M.; Komor, A.C.; Rees, H.A.; Packer, M.S.; Badran, A.H.; Bryson, D.I.; Liu, D.R. Programmable base editing of A $\bullet$ T to G•C in genomic DNA without DNA cleavage. Nature 2017, 551, 464-471. [CrossRef]

319. Komor, A.C.; Kim, Y.B.; Packer, M.S.; Zuris, J.A.; Liu, D.R. Programmable editing of a target base in genomic DNA without double-stranded DNA cleavage. Nature 2016, 533, 420-424. [CrossRef]

320. Mishra, R.; Joshi, R.K.; Zhao, K. Base editing in crops: Current advances, limitations and future implications. Plant Biotechnol. J. 2020, 18, 20-31. [CrossRef] 
321. Ren, B.; Liu, L.; Li, S.; Kuang, Y.; Wang, J.; Zhang, D.; Zhou, X.; Lin, H.; Zhou, H. Cas9-NG greatly expands the targeting scope of the genome-editing toolkit by recognizing NG and other atypical PAMs in rice. Mol. Plant 2019, 12, 1015-1026. [CrossRef]

322. Chen, X.; Zuo, S.; Schwessinger, B.; Chern, M.; Canlas, P.E.; Ruan, D.; Zhou, X.; Wang, J.; Daudi, A.; Petzold, C.J.; et al. An XA21-associated kinase (OsSERK2) regulates immunity mediated by the XA21 and XA3 immune receptors. Mol. Plant 2014, 7 , 874-892. [CrossRef]

323. Wang, Z.-Y.; Nakano, T.; Gendron, J.; He, J.; Chen, M.; Vafeados, D.; Yang, Y.; Fujioka, S.; Yoshida, S.; Asami, T.; et al. Nuclearlocalized BZR1 mediates brassinosteroid-induced growth and feedback suppression of brassinosteroid biosynthesis. Dev. Cell 2002, 2, 505-513. [CrossRef]

324. Zu, S.-H.; Jiang, Y.-T.; Hu, L.-Q.; Zhang, Y.-J.; Chang, J.-H.; Xue, H.-W.; Lin, W.-H. Effective modulating brassinosteroids signal to study their specific regulation of reproductive development and enhance yield. Front. Plant Sci. 2019, 10. [CrossRef]

325. Liu, L.; Jia, C.; Zhang, M.; Chen, D.; Chen, S.; Guo, R.; Guo, D.; Wang, Q. Ectopic expression of a BZR1-1D transcription factor in brassinosteroid signalling enhances carotenoid accumulation and fruit quality attributes in tomato. Plant Biotechnol J. 2014, 12, 105-115. [CrossRef]

326. Wu, C.; Trieu, A.; Radhakrishnan, P.; Kwok, S.F.; Harris, S.; Zhang, K.; Wang, J.; Wan, J.; Zhai, H.; Takatsuto, S.; et al. Brassinosteroids regulate grain filling in rice. Plant Cell 2008, 20, 2130-2145. [CrossRef]

327. Zuo, S.; Zhou, X.; Chen, M.; Zhang, S.; Schwessinger, B.; Ruan, D.; Yuan, C.; Wang, J.; Chen, X.; Ronald, P.C. OsSERK1 regulates rice development but not immunity to Xanthomonas oryzae Pv. oryzae or Magnaporthe oryzae. J. Integr. Plant Biol. 2014, 56, 1179-1192. [CrossRef] [PubMed]

328. Anzalone, A.V.; Randolph, P.B.; Davis, J.R.; Sousa, A.A.; Koblan, L.W.; Levy, J.M.; Chen, P.J.; Wilson, C.; Newby, G.A.; Raguram, A.; et al. Search-and-replace genome editing without double-strand breaks or donor DNA. Nature 2019, 576, 149-157. [CrossRef]

329. Lin, Q.; Zong, Y.; Xue, C.; Wang, S.; Jin, S.; Zhu, Z.; Wang, Y.; Anzalone, A.V.; Raguram, A.; Doman, J.L.; et al. Prime genome editing in rice and wheat. Nat. Biotechnol. 2020, 38, 582-585. [CrossRef]

330. Lu, P.; Guo, L.; Wang, Z.; Li, B.; Li, J.; Li, Y.; Qiu, D.; Shi, W.; Yang, L.; Wang, N.; et al. A rare gain of function mutation in a wheat tandem kinase confers resistance to powdery mildew. Nat. Commun. 2020, 11, 680. [CrossRef]

331. Vijayan, J.; Devanna, B.N.; Singh, N.K.; Sharma, T.R. Cloning and functional validation of early inducible magnaporthe oryzae responsive CYP76M7 promoter from rice. Front. Plant Sci. 2015, 6. [CrossRef]

332. Pajerowska-Mukhtar, K.M.; Wang, W.; Tada, Y.; Oka, N.; Tucker, C.L.; Fonseca, J.P.; Dong, X. The HSF-like transcription factor TBF1 is a major molecular switch for plant growth-to-defense transition. Curr. Biol. 2012, 22, 103-112. [CrossRef]

333. Blanvillain-Baufumé, S.; Reschke, M.; Solé, M.; Auguy, F.; Doucoure, H.; Szurek, B.; Meynard, D.; Portefaix, M.; Cunnac, S.; Guiderdoni, E.; et al. Targeted promoter editing for rice resistance to Xanthomonas oryzae Pv. oryzae reveals differential activities for SWEET14-inducing TAL effectors. Plant Biotechnol. J. 2017, 15, 306-317. [CrossRef]

334. Yu, Q.; Wang, B.; Li, N.; Tang, Y.; Yang, S.; Yang, T.; Xu, J.; Guo, C.; Yan, P.; Wang, Q.; et al. CRISPR/Cas9-induced targeted mutagenesis and gene replacement to generate long-shelf life tomato lines. Sci. Rep. 2017, 7. [CrossRef]

335. Gentzel, I.N.; Park, C.H.; Bellizzi, M.; Xiao, G.; Gadhave, K.R.; Murphree, C.; Yang, Q.; LaMantia, J.; Redinbaugh, M.G.; Balint-Kurti, P.; et al. A CRISPR/DCas9 toolkit for functional analysis of maize genes. Plant Methods 2020, 16, 133. [CrossRef] [PubMed]

336. Castro, P.H.; Santos, M.Â.; Freitas, S.; Cana-Quijada, P.; Lourenço, T.; Rodrigues, M.A.A.; Fonseca, F.; Ruiz-Albert, J.; Azevedo, J.E.; Tavares, R.M.; et al. Arabidopsis thaliana SPF1 and SPF2 are nuclear-located ULP2-like SUMO proteases that act downstream of SIZ1 in plant development. J. Exp. Bot. 2018, 69, 4633-4649. [CrossRef] [PubMed]

337. Garrido, E.; Srivastava, A.K.; Sadanandom, A. Exploiting protein modification systems to boost crop productivity: SUMO proteases in focus. J. Exp. Bot. 2018, 69, 4625-4632. [CrossRef]

338. Yates, G.; Srivastava, A.K.; Sadanandom, A. SUMO Proteases: Uncovering the roles of DeSUMOylation in plants. J. Exp. Bot. 2016, 67, 2541-2548. [CrossRef] [PubMed]

339. Mao, Y.; Botella, J.R.; Liu, Y.; Zhu, J.-K. Gene editing in plants: Progress and challenges. Natl. Sci. Rev. 2019, 6, 421-437. [CrossRef]

340. Chen, T.; Duan, L.; Zhou, B.; Yu, H.; Zhu, H.; Cao, Y.; Zhang, Z. Interplay of pathogen-induced defense responses and symbiotic establishment in medicago truncatula. Front. Microbiol. 2017, 8. [CrossRef]

341. Li, B.; Ferreira, M.A.; Huang, M.; Camargos, L.F.; Yu, X.; Teixeira, R.M.; Carpinetti, P.A.; Mendes, G.C.; Gouveia-Mageste, B.C.; Liu, C.; et al. The receptor-like kinase NIK1 targets FLS2/BAK1 immune complex and inversely modulates antiviral and antibacterial immunity. Nat. Commun. 2019, 10, 4996. [CrossRef] [PubMed]

342. Nelson, R.; Wiesner-Hanks, T.; Wisser, R.; Balint-Kurti, P. Navigating complexity to breed disease-resistant crops. Nat. Rev. Genet. 2018, 19, 21-33. [CrossRef]

343. McGrann, G.R.D.; Stavrinides, A.; Russell, J.; Corbitt, M.M.; Booth, A.; Chartrain, L.; Thomas, W.T.B.; Brown, J.K.M. A Trade off between Mlo Resistance to powdery mildew and increased susceptibility of barley to a newly important disease, ramularia leaf spot. J. Exp. Bot. 2014, 65, 1025-1037. [CrossRef]

344. Mitra, S.K.; Chen, R.; Dhandaydham, M.; Wang, X.; Blackburn, R.K.; Kota, U.; Goshe, M.B.; Schwartz, D.; Huber, S.C.; Clouse, S.D. An autophosphorylation site database for leucine-rich repeat receptor-like kinases in Arabidopsis thaliana. Plant J. 2015, 82, 1042-1060. [CrossRef]

345. Chang, C.-C.; Tung, C.-H.; Chen, C.-W.; Tu, C.-H.; Chu, Y.-W. SUMOgo: Prediction of sumoylation sites on lysines by motif screening models and the effects of various post-translational modifications. Sci. Rep. 2018, 8, 15512. [CrossRef] [PubMed] 
346. Mosharaf, P.; Hassan, M.; Ahmed, F.F.; Khatun, S.; Moni, M.A.; Mollah, N.H. Computational prediction of protein ubiquitination sites mapping on Arabidopsis thaliana. Comput. Biol. Chem. 2020, 85, 107238. [CrossRef] [PubMed]

347. Song, L.; Luo, Z.-Q. Post-translational regulation of ubiquitin signaling. J. Cell. Biol. 2019, 218, 1776-1786. [CrossRef] [PubMed]

348. Xu, H.; Zhou, J.; Lin, S.; Deng, W.; Zhang, Y.; Xue, Y. PLMD: An updated data resource of protein lysine modifications. J. Genet. Genom. 2017, 44, 243-250. [CrossRef]

349. Song, G.; Walley, J.W. Dynamic protein acetylation in plant-pathogen interactions. Front. Plant Sci. 2016, 7, 421. [CrossRef]

350. Walley, J.W.; Shen, Z.; McReynolds, M.R.; Schmelz, E.A.; Briggs, S.P. Fungal-induced protein hyperacetylation in maize identified by acetylome profiling. Proc. Natl. Acad. Sci. USA 2018, 115, 210-215. [CrossRef] [PubMed]

351. Swinnen, G.; Goossens, A.; Colinas, M. Metabolic editing: Small measures, great impact. Curr. Opin. Biotechnol. $2019,59,16-23$. [CrossRef] [PubMed] 